\title{
CARTILAGINOUS FISHES CCLASS CHONDRICHTHYES] FROM THE ICHTHYOLOGICAL COLLECTION AT THE FEDERAL UNIVERSITY OF PARAíBA, BRAZIL
}

\author{
PEIXES CARTILAGINOSOS (CLASSE CHONDRICHTHYESI DA COLEÇÃO ICTIOLÓGICA DA UNIVERSIDADE \\ FEDERAL DA PARAÍBA, BRASIL
}

PECES CARTILAGINOSOS (CLASSE CHONDRICHTHYESJ DE LA COLECCIÓN ICTIOLÓGICA DE LA
UNIVERSIDAD FEDERAL DE PARAÍBA, BRASIL

Sarah TFL Viana

Danilo Lima

Katherine Viana ${ }^{3}$

Antônio Felinto ${ }^{4}$

Ricardo de Souza Rosa ${ }^{5}$

\begin{abstract}
Federal University of Paraíba (UFPB) ichthyological collection comprises over 11,00o lots of species of cartilaginous and bony fishes from marine, estuarine and freshwater realms. Due to the collection size, rarity of some specimens, taxonomic and geographical scope, this collection represents a substantial archive of the Neotropical fish fauna, especially concerning the Northeast Brazilian region. Currently, UFPB fish collection is under bioinformatization and curatorial transitions. Hence, the present study aimed to provide a detailed taxonomic synthesis of the Chondrichthyan collection database in which the systematic, spatial and chronological coverages are discussed. Full list of collection objects, updated nomenclature and type collection extent are given for public consultation. There are 504 lots of sharks, batoids and chimaeras that are classified within 10 orders, 22 families, 34 genera, and 64 species. Myliobatiformes and Carcharhiniformes represent taxa with higher number of lots in which freshwater stingrays (Potamotrygonidae) and requiem sharks (Carcharhinidae) stand out. Specimens were mostly collected in the marine coastline off Paraíba state and lower Amazonian region, which set UFPB fish collection as an outstanding scientific collection of the regional genetic heritage.
\end{abstract}

\footnotetext{
1 South African Institute for Aquatic Biodiversity, Private Bag 1015, Grahamstown, 6140, South Africa. Email: stviana@gmail.com

2 Departamento de Sistemática e Ecologia, CCEN, Universidade Federal da Paraíba, Campus Universitário I, CEP 58051-900, João Pessoa, PB, Brazil.

3 Departamento de Sistemática e Ecologia, CCEN, Universidade Federal da Paraíba, Campus Universitário I, CEP 58051-90o, João Pessoa, PB, Brazil.

4 Departamento de Sistemática e Ecologia, CCEN, Universidade Federal da Paraíba, Campus Universitário I, CEP 58051-90o, João Pessoa, PB, Brazil.

5 Departamento de Sistemática e Ecologia, CCEN, Universidade Federal da Paraíba, Campus Universitário I, CEP 58051-90o, João Pessoa, PB, Brazil.
} 
Keywords: Elasmobranchii; chimaeras; taxonomy; ichthyological collection; Northeast Brazil.

\section{Resumo}

A coleção ictiológica da Universidade Federal da Paraíba (UFPB) compreende mais de 11.000 lotes de espécies de peixes cartilaginosos e ósseos de ambientes marinhos, estuarinos e dulcícolas. O tamanho, a raridade dos espécimes, e os escopos taxonômico e geográfico fazem desta coleção um significante acervo da fauna de peixes neotropicais, especialmente relativo a região do Nordeste brasileiro. Atualmente, a coleção de peixes da UFPB está sob bioinformatização e transição curatorial. Assim, o presente estudo objetivou sintetizar a base de dados referente a coleção de Chondrichthyes e discutir a distribuição sistemática, espacial e cronológica da coleção. Uma lista completa dos objetos da coleção, nomenclatura atualizada e extensão da coleção-tipo são divulgadas aqui para consulta pública. Existem 504 lotes de tubarões, raias e quimeras que estão classificadas em 10 ordens, 22 famílias, 34 gêneros e 64 espécies. Myliobatiformes e Carcharhiniformes representam taxa com maior número de lotes, sendo as raias de água doce (Potamotrygonidae) e os tubarões réquiem (Carcharhinidae) mais notados. Os espécimes foram coletados majoritariamente no Estado da Paraíba e na região do baixo Amazonas, reiterando a coleção de peixes da UFPB como uma coleção científica de renome do patrimônio genético regional.

Palavras-chave: Elasmobranchii; quimeras; taxonomia; coleção ictiológica; Nordeste do Brazil.

\section{Resumen}

La Colección Ictiológica de la Universidad Federal de Paraíba (UFPB) comprende más de 11,00o lotes de especies de peces cartilaginosos y óseos de ambientes marinos, estuarinos y de agua dulce. Debido al tamaño, la rareza de los especímenes, los ámbitos taxonómico y geográfico, esta colección representa un archivo sustancial de la fauna de peces Neotropicales, especialmente en relación a la región noreste de Brasil. Actualmente, la colección de peces de la UFPB está bajo bioinformatización y transición curatorial. Por lo tanto, el presente estudio tuvo como objetivo sintetizar la base de datos de los Chondrichthyes y analizar la distribución sistemática, espacial y cronológica de la colección. Aquí se presenta una lista completa de los objetos de colección, la nomenclatura actualizada y la extensión de la colección de tipos para consulta pública. Hay 504 lotes de tiburones, rayas y quimeras que se clasifican en 10 órdenes, 22 familias, 34 géneros y 64 especies. Myliobatiformes y Carcharhiniformes representan los taxones más comunes, con las rayas de agua dulce (Potamotrygonidae) y los tiburones réquiem (Carcharhinidae) siendo los más notables. Los especímenes se recolectaron principalmente en el estado de Paraíba y en la región del bajo Amazonas, lo que estableció la colección de peces de la UFPB como una colección científica reconocida del patrimonio genético regional. 
Palabras clave: Elasmobranchii; quimeras; taxonomia; colección ictiológica; Nordeste de Brasil.

\section{INTRODUCTION}

The Ichthyological collection at the Federal University of Paraíba (UFPB), Campus I, João Pessoa, Paraíba, represents an important zoological archive of Neotropical fish fauna and more particularly from the Brazilian Northeastern region. Established in 1977 at the Zoology Division of the Department of Systematics and Ecology (DSE) through the efforts of the former professor Dr. Graciela Cannella and Dr. Ricardo de Souza Rosa. Currently, the collection holdings comprise 11,836 catalogued lots from 692 fish species of marine and estuarine (6,097 lots, 409 species) and freshwater (5,739 lots, 283 species) realms. Myxini, Petromyzonti, Chondrichthyes and Euteleostomi (=Osteichthyes) are taxonomically classified within 39 orders, 98 families and 389 genera at total in the collection (Carvalho-Rocha et al. 2019).

Collection materials were incorporated through oceanographic and inland scientific expeditions, purchase in local fish markets, donations and/or exchange with national and international museums and institutions. These are mostly derived from adjacent Neotropical biogeographical regions such as the Tropical Atlantic Marine Bioregion within the Brazilian Northeast Exclusive Economic Zone as well as the Atlantic Forest, Caatinga and Amazonia biomes. Marine and estuarine holdings were also obtained from national marine environmentally protected areas including Fernando de Noronha, Atol das Rocas, Abrolhos, Trindade, and São Pedro and São Paulo Islands, and marine national parks such as Areia Vermelha in Paraíba State and Parcel of Manuel Luís in Maranhão State as well as artificial ecosystems (e.g. Alice and Queimado shipwrecks, Paraíba State; Ana Cristina shipwreck, Maranhão State; São Luiz shipwreck, Rio Grande do Norte State) and underwater formations (e.g. Risca do Zumbi and Parrachos de Maracajú, Rio Grande do Norte State) (CarvalhoRocha et al. 2019). UFPB fish collection hence maintains a variety of taxonomic and ecological regional data that rarely exists worldwide.

National and foreign researchers and students have visited the fish collection annually for examining specimens, collaborating in scientific manuscripts with local scientists or obtaining biodiversity data as part of related research projects. With over 40 years of dedicated curation and maintenance, UFPB fish collection has underwritten to distinctive research fields in Biology, including systematic accounts (e.g. Ramos 2003; Rosa and Gadig 2014), biogeographic studies (e.g. Feitoza et al. 2005; Francini-Filho et al. 2019), feeding ecology (e.g. Shibuya et al. 2006; Moro et al. 2012), and conservation (e.g. Rosa and Menezes 1996; Ramos et al. 2018) of fishes. Special attention to the cartilaginous fishes (sharks, batoids and chimaeras) has been performed as target taxa due to research interests of Prof. Ricardo Rosa, concurrent curator together with Dr. Robson Tamar da Costa Ramos. 
Diversity of Brazilian Chondrichthyan fauna today involves 13 orders, 37 families, 83 genera and approximately 200 recognized species, although many taxa are still awaiting systematic revision (Viana et al. 2018). The taxonomic impediment it represents is intrinsically due to unavailability of collection data and restricted accession of representatives in national zoological archives. Biodiversity collection databases thus are eminent for revealing regional knowledge gaps, speeding up project aims, and facilitate accession and exchange of related information for research, conservation and management purposes. As UFPB fish collection is still under bioinformatization process, the present study aimed to provide a detailed taxonomic synthesis and account of the Chondrichthyan collection database. Full list of collection objects, updated nomenclature and type collection extent are given for public consultation as well as systematic, geographical and chronological coverages are discussed.

\section{MATERIAL AND METHODS}

\section{Collection data}

Collection data were compiled from three catalog books of the UFPB ichthyological collection. Data were digitalized into Excel software spreadsheet. Collection data were standardized according to Wieczorek et al. (2012). Collection data consist of catalogue number, taxon full name, determiner, event number, locality name, geography, geographical coordinates, depth, collection date, collectors name, collection method, specimen count, sex, size, type status, preservation method, collection storage, and general remarks for each lot/specimen. Each original collection object and label were verified at the collection. Specimen lots are arranged in numerical system by order and family according to the fish classification of Nelson (2006), and stored in glass jars, containers and tanks of diverse sizes and shapes. Collection objects comprise whole, disarticulated (e.g. claspers) or partial (e.g. skeleton) wet specimens usually preserved in 70\% ethanol. Dry material (e.g. cranium, jaws, egg capsule), and clearing and staining specimens in double-distilled glycerin are also part of the collection holdings. Each specimen was classified according to different life stages (e.g. larvae, embryos, neonates, juveniles and adults) whenever possible. Incomplete, incorrect or mismatched collection data were verified in the historical catalog books alongside invoices and/or original curatorial documents (e.g. collecting event logbooks). Collection data is herein summarized as Appendix 1 for consultation. Type specimens are indicated in a separate list along with reference of associated original description of the nominal species and/or subsequent nomenclatural act. 


\section{Biodiversity data}

Chondrichthyan biodiversity data held at the UFPB fish collection were classified by subclass, order, family and species level. High clade nomenclature follows Naylor et al. (2012) and Last et al. (2016) for sharks and chimaeras, and batoids respectively. Doubtful species identifications were certified, and re-identifications were undertaken at the Laboratório de Ictiologia da Universidade Federal da Paraíba (LabIct-UFPB) through both expert consultation and/or using relevant identification keys, including: Gomes et al. (2010), Lasso et al. (2016), Last et al. (2016). Nomenclature was checked against Fricke et al. (2019) for updating. Vernacular names of species follow original description of nominal species or Froese and Pauly (2019) whenever available.

\section{Spatial and temporal coverage}

Locality name, geography and associated geographical coordinates for each lot/specimen were verified using Google Earth (hhtp://www.google.co.uk/intl/ en_uk/earth). Whenever these are not denoted in the collection database, latitude and longitude are estimated to the nearest locality and are given under the section "estimated coordinates". Map of geographical coverage of the UFPB ichthyological collection holdings from the Neotropical region was generated through QGIS 3.2.1 Bonn (QGIS 2018). Specimen coordinates from beyond the American continent were excluded from the map but full geographical information is provided under Appendix

1. Temporal coverage was verified according to the registered collection event and/or collecting date.

\section{RESULTS AND DISCUSSION}

\section{Chondrichthyan data at UFPB Ichthyological Collection}

Sharks, batoids and chimaeras represent a total of 504 lots and 652 catalogued specimens. These are classified within 10 orders, 22 families, 34 genera, and 64 species (Table 1; Appendix 1). It thus represents approximately $0.04 \%$ of the total specimen holdings from the UFPB Ichthyological Collection (vs. 99.06\% Osteichthyes in CarvalhoRocha et al. 2019). Batoids comprise the most representative taxa with $76.59 \%$ of the total Chondrichthyan collection whereas sharks and chimaeras have, respectively, $23.21 \%$ and $0.20 \%$. Collecting efforts were neglected for the latter two groups probably due to the difficulty on accessing material through oceanographic scientific expeditions and/or appropriate academic funding and infrastructure it requires. 
Table 1. Diversity of Chondrichthyes holdings at the UFPB Ichthyological collection.

Number of lots is given in units per genus.

\begin{tabular}{|c|c|c|c|c|}
\hline & Order & Family & Genus & Number of lots \\
\hline \multirow{16}{*}{ Sharks } & Carcharhiniformes & Carcharhinidae & Carcharhinus & 21 \\
\hline & & & Galeocerdo & 3 \\
\hline & & & Prionace & 1 \\
\hline & & & Rhizoprionodon & 57 \\
\hline & & Sphyrnidae & Sphyrna & 11 \\
\hline & & Scyliorhinidae & Scyliorhinus & 4 \\
\hline & & & Schroederichthys & 2 \\
\hline & & Tryakidae & Mustelus & 2 \\
\hline & Lamniformes & Lamnidae & Isurus & 1 \\
\hline & & Pseudocarcharhidae & Pseudocarcharhias & 2 \\
\hline & Orectolobiformes & Ginglymostomatidae & Ginglymostoma & 4 \\
\hline & Squatiniformes & Squatinidae & Squatina & 1 \\
\hline & Squaliformes & Squalidae & Squalus & 1 \\
\hline & & & Cirrhigaleus & 4 \\
\hline & & Dalatiidae & Isistius & 1 \\
\hline & & Somniosidae & Centroscymnus & 1 \\
\hline \multirow{16}{*}{ Batoids } & Myliobatiformes & Aetobatidae & Aetobatus & 3 \\
\hline & & Dasyatidae & Fontitrygon & 1 \\
\hline & & & Hypanus & 64 \\
\hline & & Gymnuridae & Gymnura & 43 \\
\hline & & Potamotrygonidae & Potamotrygon & 194 \\
\hline & & & Paratrygon & 10 \\
\hline & & & Plesiotrygon & 2 \\
\hline & & & Styracura & 5 \\
\hline & & Rhinopteridae & Rhinoptera & 1 \\
\hline & & Urotrygonidae & Urotrygon & 16 \\
\hline & & & Urobatis & 1 \\
\hline & Rajiformes & Arhynchobatidae & Rioraja & 1 \\
\hline & & & Sympterygia & 1 \\
\hline & Rhinopristiformes & Rhinobatidae & Pseudobatos & 20 \\
\hline & & Trygonorrhinidae & Zapteryx & 1 \\
\hline & Torpediniformes & Narcinidae & Narcine & 24 \\
\hline Chimaeras & Chimaeriformes & Chimaeridae & Hydrolagus & 1 \\
\hline TOTAL & & & & 504 \\
\hline
\end{tabular}

All four orders of batoids occurring in Brazil are available at UFPB fish collection in which Myliobatiformes are by far the most common taxa of the total Chondrichthyan collection followed by Torpediniformes, Rhinopristiformes and Rajiformes, respectively (Figure 1). Potamotrygonidae is amongst the family with the highest number of collection objects (41.87\% of total records) within Myliobatiformes 
and comprehends the common freshwater rays of the genera Potamotrygon Garman, 1877, Paratygon Duméril, 1865 and Plesiotrygon Rosa, Castello \& Thorson, 1987 as well as marine rare species, for instance, Styracura schmardae (Werner, 1904). Dasyatidae, Gymnuridae and Urotrygonidae represent $12.90 \%, 8.53 \%$ and 3.37\%, respectively, and denote an extensive number of specimens of Hypanus guttatus (Bloch \& Schneider, 1801) and H. marianae Gomes, Rosa \& Gadig, 2000, Gymnura micrura (Bloch \& Schneider, 1801), and Urotrygon microphthalmum Delsman, 1941 (Table 1). Electric rays of Torpediniformes are exclusively from the family Narcinidae representing $4.76 \%$ with two species available: N. brasiliensis (Olfers, 1831) and N. bancroftii (Griffith \& Smith, 1834). Specimens of these species from the Brazilian Northeast region are extremely rare in fish collections which makes UFPB ichthyological collection a reference database for future systematics and ecological studies. A total of 21 records of Rhinopristiformes are available in which $95.24 \%$ of them belong to the South American guitarrays of the family Rhinobatidae, more particularly Pseudobatos percellens (Walbaum, 1792), whilst Trygonorrhinidae represents $4.76 \%$ of the group with a single specimen of the regional endemic, Zapteryx brevirostris (Müller \& Henle, 1841). Aetobatus narinari (Euphrasen, 1790) (Aetobatidae), Rhinoptera bonasus (Mitchill, 1815) (Rhinopteridae) as well as two deep-water skates Rioraja agassizi (Müller \& Henle, 1841) and Sympterygia acuta Garman, 1877 (Arrhynchobatidae) denote less than $1.0 \%$ of the total lots.
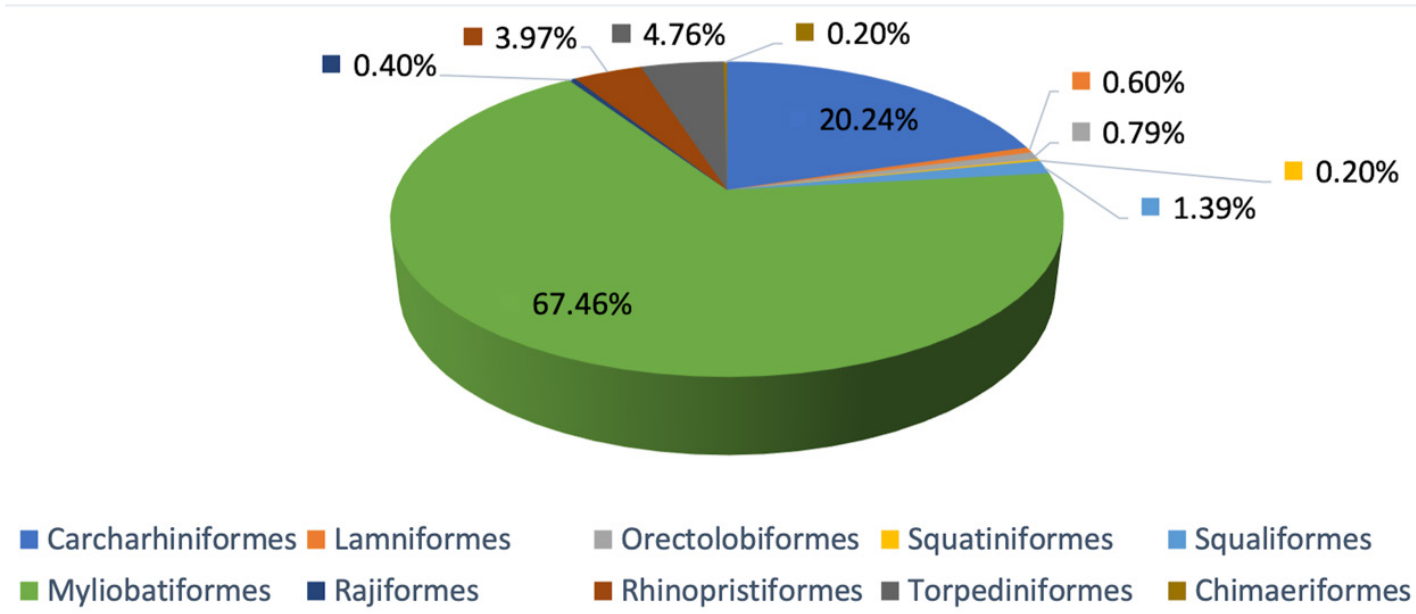

Figure 1. Number of lots by order at UFPB Chondrichthyan collection expressed in percentage.

All seven orders of sharks occurring in Brazil are represented in the collection with exception to Hexanchiformes. Carcharhiniformes is the order with the highest number of lots while Squaliformes, Squatiniformes, Orectolobiformes, Lamniformes represent near or less than 1.0\% (Figure 1). Carcharhinidae has the second highest number of collection objects within Chondrichthyan families ( $16.47 \%$ of total lots) 
and prevails within Carcharhiniformes with $81.93 \%$ of total specimens in which Carcharhinus acronotus (Poey, 1860), C. limbatus (Valenciennes, 1839), C. plumbeus (Nardo, 1827) and Rhizoprionodon porosus (Poey, 1861) are the most common species. Scyliorhinidae and Sphyrnidae bear, respectively, $12.65 \%$ and $4.22 \%$ of total specimens of Carcharhiniformes with Scyliorhinus haeckelii (Miranda-Ribeiro, 1907) and Sphyrna tiburo (Linnaeus, 1758) as the species with the greatest specimen counts. Despite Triakidae exhibits only o.40\% of total lots, Mustelus higmani Springer \& Lowe, 1963 and $M$. canis (Mitchill, 1815) represent one of the few records collected from the Brazilian Northeastern region. A single specimen of Isurus oxyrinchus Rafinesque, 1810 (Lamnidae) is also available. Species rarely found in scientific collections such as Pseudocarcharias kamoharai (Matsubara, 1936) (Pseudocarcharidae) are also represented in the fish collection with two specimens collected from Natal, Rio Grande do Norte State through landings of the local industrial fishing fleets. There are only three families of Squaliformes: Squalidae, Dalatiidae and Somniosidae that comprise seven specimens at total. Cirrhigaleus asper (Merrett, 1973), Isistius brasiliensis (Quoy \& Gainard, 1824) and Centroscymnus owstonii Garman, 1906 whose specimens were all collected in the country are deep-water dogfish species that are also rarely found in Brazilian Ichthyological collections. Squatina guggenheim Marine, 1936 is the only species of angel sharks verified herein with one collection object from Rio de Janeiro, Brazil. Two specimens of the spotted ratfish Hydrolagus colliei (Lay \& Bennett, 1839) from Washington State, USA represents the Chimaeriformes and were obtained as a donation from the Museum of Zoology, University of Alberta, Canada.

Ten paratypes are deposited at UFPB fish collection belonging to two endemic species, the Brazilian large-eyed stingray $H$. marianae and the "raia cururu" Potamotrygon wallacei Carvalho, Rosa \& Araújo, 2016 (Table 2). These paratypes were designated through collaborative taxonomic studies of Prof. Ricardo Rosa and a number of other national shark experts. Type material are currently stored in a separate metal cabinet for safety and better preservation of specimens.

Table 2. List of type material from UFPB Chondrichthyan collection. N: number of specimens.

\begin{tabular}{ccccc}
\hline Nominal species & Authorship & Catalog number & Type status & N \\
\hline Hypanus marianae & (Gomes, Rosa \& Gadig, 2000) & UFPB 663 & Paratype & 1 \\
& & UFPB 2661 & Paratype & 1 \\
& & UFPB 2790 & Paratype & 1 \\
Potamotrygon wallacei & \multirow{2}{*}{ Carvalho, Rosa \& Araújo, 2016 } & UFPB 3283 & Paratype & 1 \\
& & UFPB 4238 & Paratype & 1 \\
& & UFPB 3543 & Paratype & 1 \\
TOTAL & UFP 4866 & Paratype & 1 \\
& & UFPB 4867 & Paratype & 1 \\
& & UFPB 9017 & Paratype & 2 \\
& & & & 9 \\
\hline
\end{tabular}




\section{Spatial coverage}

Collection material were caught more exclusively from the Neotropical region between Colombia, Venezuela, North and South Brazil to Argentina (Figure 2a). Brazilian specimens conquer other localities, denoting 97.02\% of the total Chondrichthyan collection. Collection holdings are predominantly from the Northeast Brazil following by North and Southeast regions, respectively. South and Central-Western Brazil represent less than 1\% (Figure 2b). Paraíba, Pará and Piauí States contribute, respectively, with 37.63\%, 22.70\% and 21.68\% which makes UFPB fish collection the richest biodiversity archive concerning the Brazilian Tropical South America Chondrichthyan fauna when compared to other national institutes with online database available on GBIF (2019) and speciesLink (CRIA, 2019).
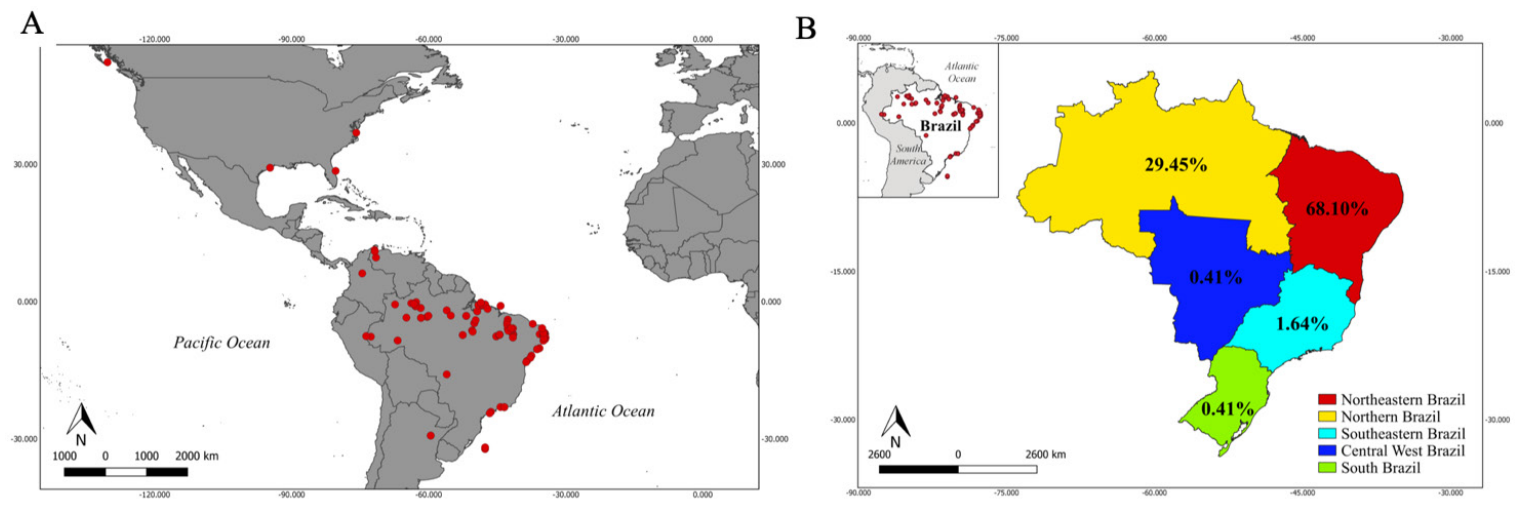

Figure 2. Locality records (red circles) of specimens from UFPB Chondrichthyan collection in the American continent (a) and number of lots by political region from Brazil (b) expressed in percentage.

Colombia, Venezuela and Argentina specimens represent less than 1\% and usually are for regional endemic species. Potamotrygon magdalenae (Duméril, 1865) has one lot with two specimens caught from Rio Magdalena Basin in Colombia. Three lots with two specimens each of Potamotrygon yepezi Castex \& Castello, 1970, a species endemic to Venezuela and Colombia, are also available in the collection. Potamotrygon motoro (Müller \& Henle, 1841) is represented by three specimens collected from Rio Geronimo, Argentina and more three others with no specific locality and geography. Specimens from the United States of America comprise 1.23\% such as a single specimen of the yellow stingray Urobatis jamaicensis (Cuvier, 1916) collected off Florida coast. These collection objects were all obtained as a gift or exchange from different foreign institutions and experts. 


\section{Temporal coverage and collecting method}

The first specimen (UFPB 1358) acquired dates back to 1976, one year prior to the foundation of UFPB fish collection, and it belongs to P. magdalenae collected by Thomas B. Thorson (University of Nebraska-Lincoln). After that, most of the specimens that were aggregated came from donations and/or sent as gift by local scientists, including Alfredo Langguth and Carmen Alonso (UFPB), Michael Goulding (INPA), and Juraci de Melo Peixoto. Collecting efforts were more apparent between 1990 and 2010 with over 300 lots of sharks and batoids indexed in the collection (Figure 3). These results uncover the project achievements that were conducted at the LabIct-UFPB in the last 40 years of research in which most of them came from individual projects of local students and fish experts. Others came from projects in partnership with other labs, more importantly, the shrimp and shark projects from NEPREMAR expedition between 1994-2000. Many specimens were also obtained from fish markets and/or collaboration with local fishermen from the artisanal fisheries sector. Fishing gears comprised beach seine, longlines, pelagic trawls, demersal traps, and gill nets.

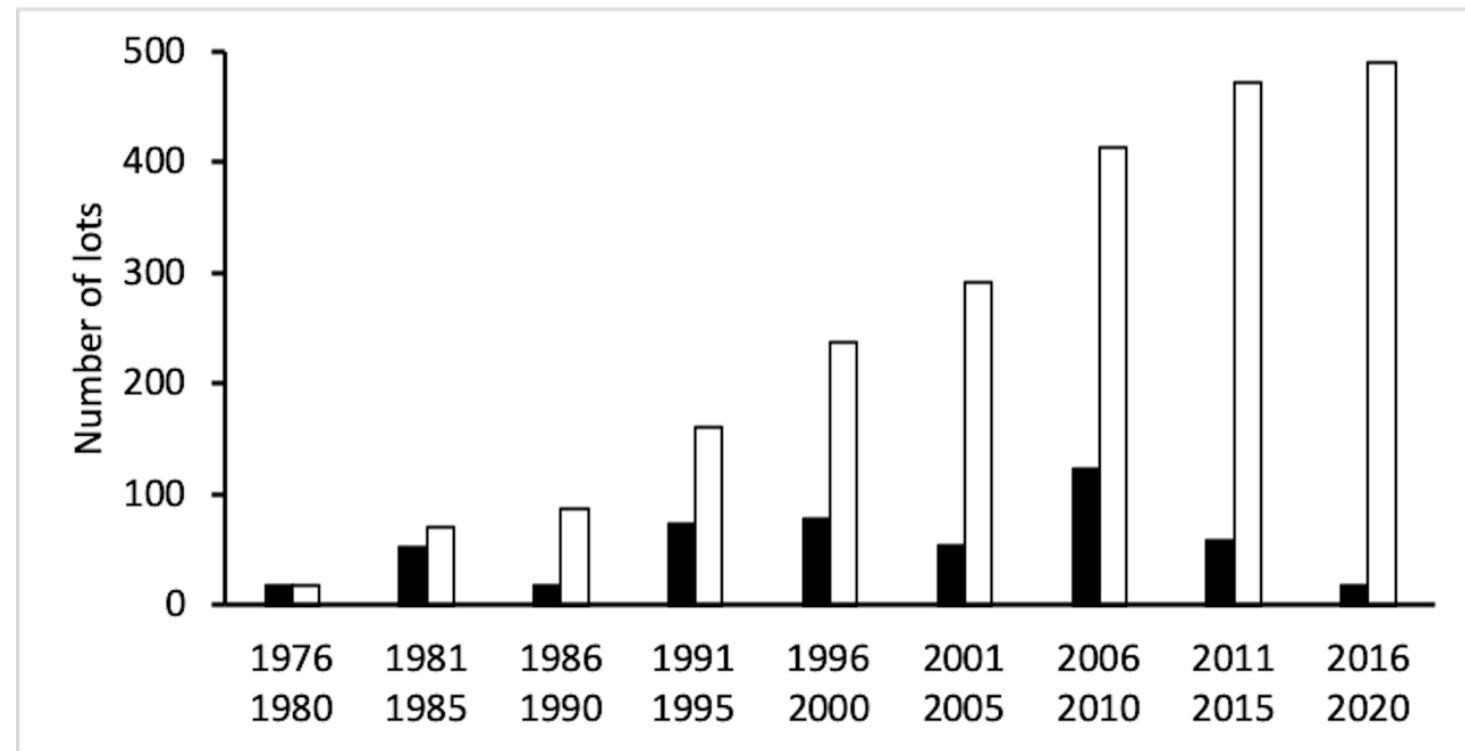

Figure 3. Collecting efforts from UFPB fish collection database, showing the number of Chondrichthyan lots with registered collection date that were obtained in the last 40 years. Collection expansion showed as absolute (black bars) and cumulative (white bars) values in 5 -year accession. 


\section{Curatorial framework and bioinformatization}

As a principle from the Convention on Biological Diversity (CBD) signed by the parties during the Eco Rio 1992 event and consolidated by the Brazilian law through the "Decreto Legislativo ${ }^{\circ}$ 2, de 1994", the ex situ complementary conservation has its basis in the maintenance of biological collections and the associated data. Starting in 2016, UFPB fish collection data has been under migration to Specify 6 software in order to guarantee the availability of biodiversity data for worldwide consultation. It is expected to accomplish this goal the soonest as it will strengthen the scientific and educational practices of the collection by engaging new visitors including scientists, students, teachers, conservationists and decision-makers from Brazil and abroad. Besides, it will guarantee permanent data quality through accurate taxonomic identification of specimens. Currently, there are more than 250 collection objects of sharks and batoids still to be incorporated to the database in which over 100 specimens are awaiting taxonomic determination.

The Brazilian Northeast region has suffered the worse marine environmental disaster of all times since last September. Mysterious spills of crude oil from uncertain origin have reached over $2,000 \mathrm{~km}$ of the coastline and no emergency actions have been carried out by the federal government to address this crisis and measure its extent. The massive environmental impact behind it hampers the local biodiversity as it will possibly induce to extinction risks of many species that are native, rare or endemic and yet little known to Science. Curatorial initiatives like the above set the UFPB fish collection, thus, as a reference database with unique historical value of the Brazilian diversity heritage. Its associated data are empirical for the regional conservation assessments that are now critical, and improvement of the biodiversity knowledge (including systematics, ecology and biology) of these taxa.

\section{CONCLUSION}

A total of 504 lots from 10 orders, 22 families, 34 genera, and 64 species of sharks, batoids and chimaeras are available at UFPB ichthyological collection. Batoids comprise the most common collection holdings (lots/specimens) when compared to sharks and chimaeras, and Myliobatiformes and Carcharhiniformes represent taxa with higher number of lots. The collection encompasses Brazilian specimens collected in the marine coastline off Paraíba State and freshwater river basins from the lower Amazonian region in its majority. Thus, UFPB fish collection houses one of the most significant archives of the Chondrichthyan fauna from the Tropical South America due to the rarity of the specimens it houses and the geographical coverage it presents. The cultural and genetic heritage behind it reveal the substantial value of this institution and that establishing and caring of zoological collections in Brazil are fundamental for different purposes that go beyond the scientific point 
of view, including food security, preservation of natural resources, community engagement and educational activities. Currently, UFPB fish collection is under transitional curatorial process regarding its infrastructure and management with the bioinformatization of the database as well as curation replacement due to the retirement of the latter author of this study. Forty-years collection efforts indubitably consolidated UFPB as a highly renowned academic environment in Ichthyology for future generation of researchers to come.

\section{ACKNOWLEDGMENTS}

Technicians and volunteers from the Laboratório de Ictiologia (LabIct-UFPB), particularly Creuza S Cortez, Fagner Delfim and Gabriel Beltrão are thanked for their curatorial assistance. Thanks also to the students Thais RS Domingos, Marcus VG Araújo, Jade MF Cardoso and Henrique B Malfado (LabIct-UFPB) for helping with data acquisition. Special thanks to Mark Lisher (SAMS) for bringing up the manuscript idea, his suggestions and English review. D Pinto and K Viana were funded by Conselho Nacional de Desenvolvimento Científico e Tecnológico (CNPq: 146523/2018-0; 153797/2014-2 and 127234/2015-2).

\section{REFERENCES}

Carvalho-Rocha YGP, Beltrão GBM, Cortez SC, Sales J, Figueiredo-Filho JM, Freitas NDA, Ramos TPA, Oliveira-Silva L, Ramos RTC, Rosa RS. 2019. Forty years of the Ichthyological Collection of Universidade Federal da Paraíba. Boletim Sociedade Brasileira de Ictiologia, 129:137-139.

CRIA: Centro de Referência e Informação Ambiental. 2011. SpeciesLink - simple search. Available at: http://www.splink.org.br/index, Accessed on 10 July 2019.

Feitoza BM, Rosa RS, Rocha Filho LA. Ecology and zoogeography of deep-reef fishes in northeastern Brazil. Bulletin of Marine Science,76(3):725-742.

Francini-Filho RB, Velásquez Márquez V, Silva MB, Rosa MR, Sumida PYG et al. 2019. Brazil. In: Loya Y (Ed.), Coral Reefs of the World, ist ed, Springer International Publishing: p.163-198. https://doi.org/10.1007/978-3-319-92735-0_10

Froese R, Pauly D (Eds.). 2019.FishBase. Available at: www.fishbase.org, Accessed on 10 July 2019. 
GBIF: The Global Biodiversity Information Facility Home Page. Available at: https:// www.gbif.org, Accessed on 10 July 2019.

Gomes UL, Signori CN, Gadig OBF, Santos HRS. 2010. Guia para a identificação de tubarões e raias do Rio de Janeiro, Rio de Janeiro: Technical Books, 234p.

Lasso CA, Rosa RS, Morales-Betancourt M, Garrone-Neto D, Carvalho MR. 2016. Rayas de agua dulce (Potamotrygonidae) de Suramérica. Parte II: Colombia, Brasil, Perú, Bolivia, Paraguay, Uruguay y Argentina, 1st ed., Bogotá: Instituto de Investigación de Recursos Biológicos Alexander von Humboldt, 435 p.

Last PR, White WT, Carvalho MR, Séret B, Stehmann MFW, Naylor GJP (Eds). 2016b. Rays of the World. Melbourne: CSIRO Publishing, 1577 p.

Moro G, Charvet P, Rosa RS. 2012. Insectivoryin Potamotrygon signata (Chondrichthyes: Potamotrygonidae), an endemic freshwater stingray from the Parnaíba River basin, northeastern Brazil. Brazilian Journal of Biology, 72:885-891. http://dx.doi. org/10.1590/S1519-69842012000500015

Naylor GJP, Caira JN, Jensen K, Rosana AM, Straube N, Lakner C. 2012. Elasmobranch Phylogeny: A mitochondrial estimate based on 595 species. In: Carrier JC, Musick JA, Heithaus ME (Eds.), Biology of Sharks and their relatives, 2nd ed., Boca Raton, Florida: CRC Press, p.31-56.

Nelson JS. 2006. Fishes of the World, 4th ed., Hoboken, New Jersey: John Wiley \& Sons, $601 \mathrm{p}$.

Quantum GIS Development Team. 2018. Quantum GIS Geographic Information System, Open Source Geospatial Foundation Project; http://qgis.osgeo.org/).

Ramos RTC. 2003. Systematic review of Apionichthys (Pleuronectiformes: Achiridae), with description of four new species. Ichthyological Exploration of Freshwaters, 14(2): 97-126.

Ramos RTC, Sampaio CLS, Mincarone MM, Mendes LF, Gasparini JLR. 2018. Achirus mucuri Ramos, Ramos \& Lopes, 2009. In: Subirá RJ (Ed.), Livro Vermelho da Fauna Brasileira Ameaçada de Extinção, 1st ed., Brasília: ICMBio/MMA,volume 6, p. 933-935.

Rosa RS, Gadig OBF. 2014. Conhecimento da diversidade dos Chondrichthyes marinhos no Brasil: a contribuição de José Lima de Figueiredo. Arquivos de Zoologia, 45:89-104. https://doi.org/10.116o6/issn.2176-7793.v45iespp89-104 
Rosa RS, Menezes NA. 1996. Relação preliminar das espécies de peixes (Pisces, Elasmobranchii, Actinopterygii) ameacadas no Brasil. Revista Brasileira de Zoologia, 13(3):647-667. http://dx.doi.org/10.1590/So101-81751996000300015.

Shibuya A, Rosa RS, Gadig OBF. 2006. Stomach contents of Galeocerdo cuvier e Carcharhinus plumbeus (Elasmobranchii: Carcharhinidae) caught off Paraíba State, Brazil. Arquivos de Ciências do Mar, 38:105-107. https://doi.org/10.3236o/acmar.v38i12.6401

Viana STFL, Gadig OBF, Rosa RS. 2018. Advances of Chondrichthyan systematics in Brazil: an historical overview and future research perspectives. In: Moraes CRF, Faria VV, Rolim FA, Cotton CF, Gadig OBF, Rosa RS, III Sharks International Conference, Abstract Book, João Pessoa: Editora UFPB, p. 435.

Wieczorek JD, Bloom R, Guralnick S, Blum M, Döring R, Giovanni, Vieglais D. 2012. Darwin Core: an evolving community-developed biodiversity data standard. PloS one 7(1): e29715. https://doi.org/10.1371/journal.pone.0029715 
Appendix 1. Summarized database from the UFPB Chondrichthyan collection given in increasing order of catalog number. CN: catalog number; S: State; C: count.

\begin{tabular}{|c|c|c|c|c|c|c|c|c|}
\hline $\mathrm{CN}$ & Family & $\begin{array}{c}\text { Taxon } \\
\text { (full name) }\end{array}$ & Locality & $\mathbf{S}$ & Country & Latitude & Longitude & C \\
\hline 13 & Carcharhinidae & Carcharhinus porosus & Praia do Bessa & $\mathrm{PB}$ & Brazil & & & 1 \\
\hline 194 & Dasyatidae & Hypanus guttatus & Cabedelo & $\mathrm{PB}$ & Brazil & & & 1 \\
\hline 233 & Narcinidae & Narcine brasiliensis & Cabedelo & $\mathrm{PB}$ & Brazil & & & 1 \\
\hline 320 & Carcharhinidae & Rhizoprionodon porosus & Cabedelo & $\mathrm{PB}$ & Brazil & & & 1 \\
\hline 321 & Carcharhinidae & Rhizoprionodon porosus & Cabedelo & $\mathrm{PB}$ & Brazil & & & 1 \\
\hline 323 & Urotrygonidae & Urotrygon microphthalmum & Cabedelo & $\mathrm{PB}$ & Brazil & & & 3 \\
\hline 538 & Narcinidae & Narcine brasiliensis & Rio Paraíba, Costinha, Município de Lucena & $\mathrm{PB}$ & Brazil & & & 1 \\
\hline 578 & Dasyatidae & Hypanus guttatus & Praia de Tibau, Município de Areia Branca & $\mathrm{RN}$ & Brazil & & & 1 \\
\hline 663 & Dasyatidae & Hypanus marianae & Rio Paraíba do Norte, Cabedelo & $\mathrm{PB}$ & Brazil & & & 1 \\
\hline 771 & Narcinidae & Narcine brasiliensis & Praia de Costinha, Lucena & $\mathrm{PB}$ & Brazil & & & 1 \\
\hline 841 & Carcharhinidae & Rhizoprionodon porosus & Praia de Cabedelo & $\mathrm{PB}$ & Brazil & & & 1 \\
\hline 985 & Carcharhinidae & Rhizoprionodon porosus & Praia de Tambaú, João Pessoa & $\mathrm{PB}$ & Brazil & & & 10 \\
\hline 1099 & Carcharhinidae & Rhizoprionodon porosus & Praia de Camboinha, Cabedelo & $\mathrm{PB}$ & Brazil & & & 1 \\
\hline 1100 & Carcharhinidae & Carcharhinus porosus & Praia de Costinha, Lucena & $\mathrm{PB}$ & Brazil & & & 1 \\
\hline 1110 & Carcharhinidae & Rhizoprionodon porosus & Praia de Tambaú, João Pessoa & $\mathrm{PB}$ & Brazil & & & 1 \\
\hline 1111 & Rhinobatidae & Pseudobatos percellens & Praia de Lucena, Lucena & $\mathrm{PB}$ & Brazil & & & 1 \\
\hline 1112 & Gymnuridae & Gymnura micrura & Praia de Tambaú, João Pessoa & $\mathrm{PB}$ & Brazil & & & 1 \\
\hline 1113 & Urotrygonidae & Urotrygon microphthalmum & Praia de Manaíra, João Pessoa & $\mathrm{PB}$ & Brazil & & & 1 \\
\hline 1117 & Carcharhinidae & Carcharhinus porosus & Praia de Tambaú, João Pessoa & $\mathrm{PB}$ & Brazil & & & 1 \\
\hline 1118 & Carcharhinidae & Rhizoprionodon porosus & Baía da Traição & $\mathrm{PB}$ & Brazil & & & 1 \\
\hline 1119 & Carcharhinidae & Rhizoprionodon porosus & Praia de Tambaú, João Pessoa & $\mathrm{PB}$ & Brazil & & & 1 \\
\hline 1133 & Sphyrnidae & Sphyrna lewini & Praia de Cabedelo, Cabedelo & $\mathrm{PB}$ & Brazil & & & 1 \\
\hline 1207 & Narcinidae & Narcine brasiliensis & Praia do Poço, Cabedelo & $\mathrm{PB}$ & Brazil & & & 1 \\
\hline 1210 & Rhinobatidae & Pseudobatos percellens & Praia do Poço, Cabedelo & PB & Brazil & & & 1 \\
\hline
\end{tabular}




\begin{tabular}{|c|c|c|c|c|c|c|c|c|}
\hline $\mathrm{CN}$ & Family & $\begin{array}{c}\text { Taxon } \\
\text { (full name) }\end{array}$ & Locality & S & Country & Latitude & Longitude & C \\
\hline 1230 & Urotrygonidae & Urotrygon microphthalmum & Cabo Branco, João Pessoa & PB & Brazil & & & 2 \\
\hline 1231 & Urotrygonidae & Urotrygon microphthalmum & Praia de Tambaú, João Pessoa & PB & Brazil & & & 2 \\
\hline 1232 & Potamotrygonidae & Potamotrygon falkineri & $\begin{array}{l}\text { Rio Cuiabá, Volta Grande, Santo Antônio de } \\
\text { Leverger }\end{array}$ & MT & Brazil & & & 1 \\
\hline 1282 & Narcinidae & Narcine brasiliensis & Praia do Cabo Branco, João Pessoa & $\mathrm{PB}$ & Brazil & & & 1 \\
\hline 1358 & Potamotrygonidae & Potamotrygon magdalenae & Bacia do Rio Magdalena, próximo a San Cristobal & - & Colombia & & & 2 \\
\hline 1427 & Potamotrygonidae & Potamotrygon yepezi & Lago de Maracaibo & - & Venezuela & & & 2 \\
\hline 1428 & Potamotrygonidae & Potamotrygon yepezi & Ciénaga Gran Eneal, NW of Sinamaica, Zulia & - & Venezuela & & & 2 \\
\hline 1429 & Potamotrygonidae & Potamotrygon yepezi & Rio Limon, El Sargento, SW de Carrasquero, Zulia & - & Venezuela & & & 2 \\
\hline 1442 & Carcharhinidae & Rhizoprionodon porosus & Praia de Lucena, Lucena & $\mathrm{PB}$ & Brazil & & & 1 \\
\hline 1443 & Sphyrnidae & Sphyrna tiburo & Praia de Jacumã, Conde & PB & Brazil & & & 1 \\
\hline 1444 & Carcharhinidae & Rhizoprionodon porosus & Praia de Tambaú, , João Pessoa & PB & Brazil & & & 1 \\
\hline 1445 & Carcharhinidae & Rhizoprionodon porosus & Praia de Tambaú, João Pessoa & PB & Brazil & & & 6 \\
\hline 1447 & Carcharhinidae & Rhizoprionodon porosus & Praia de Lucena, Lucena & $\mathrm{PB}$ & Brazil & & & 1 \\
\hline 1448 & Carcharhinidae & Rhizoprionodon porosus & Praia de Lucena, Lucena & $\mathrm{PB}$ & Brazil & & & 1 \\
\hline 1449 & Narcinidae & Narcine brasiliensis & Praia de Manaíra, João Pessoa & $\mathrm{PB}$ & Brazil & & & 1 \\
\hline 1450 & Potamotrygonidae & Paratrygon aiereba & sem local & - & - & & & 1 \\
\hline 1451 & Potamotrygonidae & Paratrygon aiereba & sem local & - & - & & & 1 \\
\hline 1452 & Potamotrygonidae & Paratrygon aiereba & sem local & - & - & & & 1 \\
\hline 1453 & Potamotrygonidae & Paratrygon aiereba & Souzel, Rio Xingu & PA & Brazil & & & 1 \\
\hline 1454 & Potamotrygonidae & Potamotrygon henlei & Pedral, Rio Itacaiúnas & PA & Brazil & & & 1 \\
\hline 1455 & Potamotrygonidae & Potamotrygon henlei & sem local & - & - & & & 2 \\
\hline 1463 & Potamotrygonidae & Potamotrygon henlei & Rio Tocantins, $36 \mathrm{~km}$ ao Sul de Tucuruí & PA & Brazil & & & 2 \\
\hline 1464 & Urotrygonidae & Urotrygon microphthalmum & Baía da Traição, Baía da Traição & $\mathrm{PB}$ & Brazil & & & 2 \\
\hline 1465 & Urotrygonidae & Urotrygon microhpthalmum & Praia de Manaíra, João Pessoa & $\mathrm{PB}$ & Brazil & & & 1 \\
\hline 1466 & Gymnuridae & Gymnura micrura & Praia de Tambaú, João Pessoa & $\mathrm{PB}$ & Brazil & & & 2 \\
\hline 1467 & Gymnuridae & Gymnura micrura & Praia de Manaíra, João Pessoa & $\mathrm{PB}$ & Brazil & & & 1 \\
\hline 1468 & Urotrygonidae & Urotrygon microhpthalmum & Praia de Tambaú, João Pessoa & $\mathrm{PB}$ & Brazil & & & 1 \\
\hline
\end{tabular}




\begin{tabular}{|c|c|c|c|c|c|c|c|c|}
\hline $\mathrm{CN}$ & Family & $\begin{array}{l}\text { Taxon } \\
\text { (full name) }\end{array}$ & Locality & $\mathbf{S}$ & Country & Latitude & Longitude & C \\
\hline 1469 & Rhinobatidae & Pseudobatos percellens & Praia de Tambaú, João Pessoa & $\mathrm{PB}$ & Brazil & & & 1 \\
\hline 1470 & Rhinobatidae & Pseudobatos percellens & Praia de Manaíra, João Pessoa & $\mathrm{PB}$ & Brazil & & & 1 \\
\hline 1471 & Narcinidae & Narcine brasiliensis & Praia do Forte, Cabedelo & $\mathrm{PB}$ & Brazil & & & 1 \\
\hline 1472 & Carcharhinidae & Rhizoprionodon porosus & Costa da Paraíba & $\mathrm{PB}$ & Brazil & & & 11 \\
\hline 1473 & Potamotrygonidae & Potamotrygon falkneri & Serra do Moa, Rio Moa & $\mathrm{AC}$ & Brazil & & & 1 \\
\hline 1474 & Potamotrygonidae & Potamotrygon motoro & $\begin{array}{l}\text { Volta Grande, Município de Santo Antônio do } \\
\text { Leverger }\end{array}$ & MT & Brazil & & & 1 \\
\hline 1475 & Potamotrygonidae & Potamotrygon sp. & Rio Juruá, Cruzeiro do Sul & $\mathrm{AC}$ & Brazil & & & 1 \\
\hline 1480 & Squalidae & Squalus acanthias & Costa da Virgínia, Virgínia & - & USA & & & 1 \\
\hline 1481 & Urotrygonidae & Urobatis jamaicensis & Costa da Flórida, Flórida & - & USA & & & 1 \\
\hline 1517 & Rhinobatidae & Pseudobatos percellens & Praia de Tambaú, João Pessoa & $\mathrm{PB}$ & Brazil & & & 1 \\
\hline 1518 & Potamotrygonidae & Potamotrygon signata & $\begin{array}{l}\text { Rio Sambito, afluente do Rio Poti, Fazenda Lagoa } \\
\text { do Saco, Aroazes }\end{array}$ & PI & Brazil & & & 1 \\
\hline 1519 & Potamotrygonidae & Potamotrygon signata & $\begin{array}{l}\text { Rio Sambito, afluente do Rio Poti, Fazenda Lagoa } \\
\text { do Saco, Aroazes }\end{array}$ & PI & Brazil & & & 1 \\
\hline 1520 & Rhinobatidae & Pseudobatos percellens & Praia de Tambaú, João Pessoa & $\mathrm{PB}$ & Brazil & & & 1 \\
\hline 1521 & Sphyrnidae & Sphyrna tiburo & Praia de Tambaú, João Pessoa & $\mathrm{PB}$ & Brazil & & & 1 \\
\hline 1530 & Carcharhinidae & Rhizoprionodon porosus & Praia de Tambaú, João Pessoa & $\mathrm{PB}$ & Brazil & & & 1 \\
\hline 1742 & Dasyatidae & Hypanus guttatus & Praia de Tambaú, João Pessoa & $\mathrm{PB}$ & Brazil & & & 1 \\
\hline 1753 & Ginglymostomatidae & Ginglymostoma cirratum & Praia de Coqueirinho, Conde & PB & Brazil & & & 1 \\
\hline 1761 & Squatinidae & Squatina guggenheim & Angra dos Reis & $\mathrm{RJ}$ & Brazil & & & 1 \\
\hline 1762 & Chimaeridade & Hydrolagus colliei & Costa do Estado de Washington & - & USA & & & 2 \\
\hline 1767 & Sphyrnidae & Sphyrna tiburo & Praia do Jacarapé, João Pessoa & $\mathrm{PB}$ & Brazil & & & 1 \\
\hline 1929 & Dasyatidae & Hypanus guttatus & Praia do Sol, João Pessoa & $\mathrm{PB}$ & Brazil & & & 1 \\
\hline 1971 & Urotrygonidae & Urotrygon microphthalmum & Praia de Tambaú, João Pessoa & $\mathrm{PB}$ & Brazil & & & 1 \\
\hline 1972 & Ginglymostomatidae & Ginglymostoma cirratum & Praia de Coqueirinho, Conde & $\mathrm{PB}$ & Brazil & & & 1 \\
\hline 2100 & Carcharhinidae & Rhizoprionodon porosus & Praia de Tambaú & $\mathrm{PB}$ & Brazil & & & 1 \\
\hline 2216 & Dasyatidae & Hypanus guttatus & Praia de Gramame, João Pessoa & $\mathrm{PB}$ & Brazil & & & 1 \\
\hline 2217 & Dasyatidae & Hypanus guttatus & Praia de Gramame, João Pessoa & $\mathrm{PB}$ & Brazil & & & 1 \\
\hline
\end{tabular}




\begin{tabular}{|c|c|c|c|c|c|c|c|c|}
\hline $\mathrm{CN}$ & Family & $\begin{array}{c}\text { Taxon } \\
\text { (full name) }\end{array}$ & Locality & $\mathbf{S}$ & Country & Latitude & Longitude & $\mathrm{C}$ \\
\hline 2563 & Scyliorhinidae & Schroederichthys tenuis & Costa do Amapá, Oceano Atlântico & AP & Brazil & $04^{\circ} 4 \mathrm{o}^{\prime} \mathrm{N}$ & $50^{\circ} \mathrm{O} 3^{\prime} \mathrm{W}$ & 2 \\
\hline 2564 & Scyliorhinidae & Schroederichthys tenuis & Costa do Amapá, Oceano Atlântico & $\mathrm{AP}$ & Brazil & $04^{\circ} 40^{\prime} \mathrm{N}$ & $50^{\circ} \mathrm{O} 3^{\prime} \mathrm{W}$ & 1 \\
\hline 2661 & Dasyatidae & Hypanus marianae & Praia de Manaíra, João Pessoa & $\mathrm{PB}$ & Brazil & & & 1 \\
\hline 2663 & Sphyrnidae & Sphyrna media & Costa do Amapá, Oceano Atlântico & AP & Brazil & $04^{\circ} 40^{\prime} \mathrm{N}$ & & 10 \\
\hline 2664 & Sphyrnidae & Sphyrna media & Costa do Amapá, Oceano Atlântico & AP & Brazil & $04^{\circ} 40^{\prime} \mathrm{N}$ & & 2 \\
\hline 2665 & Sphyrnidae & Sphyrna tudes & Costa do Amapá, Oceano Atlântico & AP & Brazil & $04^{\circ} 40^{\prime} \mathrm{N}$ & & 1 \\
\hline 2666 & Scyliorhinidae & Scyliorhinus haeckeli & Litoral São Paulo & SP & Brazil & & & 1 \\
\hline 2667 & Narcinidae & Narcine brasiliensis & Litoral São Paulo & SP & Brazil & & & 3 \\
\hline 2668 & Narcinidae & Narcine brasiliensis & Praia de Tambaú, João Pessoa & $\mathrm{PB}$ & Brazil & & & 1 \\
\hline 2669 & Dalatiidae & Isistius brasiliensis & Litoral de São Paulo, aprox. 90 milhas da costa & SP & Brazil & & & 1 \\
\hline 2732 & Carcharhinidae & Carcharhinus acronotus & Baía da Traição & $\mathrm{PB}$ & Brazil & & & 1 \\
\hline 2733 & Narcinidae & Narcine brasiliensis & Praia de Jacumã, Conde & $\mathrm{PB}$ & Brazil & & & 2 \\
\hline 2735 & Narcinidae & Narcine brasiliensis & Praia de Jacumã, Conde & $\mathrm{PB}$ & Brazil & & & 1 \\
\hline 2736 & Urotrygonidae & Urotrygon microphthalmum & Baía da Traição & $\mathrm{PB}$ & Brazil & & & 4 \\
\hline 2737 & Gymnuridae & Gymnura micrura & Baía da Traição & $\mathrm{PB}$ & Brazil & & & 6 \\
\hline 2738 & Gymnuridae & Gymnura micrura & Praia de Jacumã, Conde & $\mathrm{PB}$ & Brazil & & & 1 \\
\hline 2739 & Narcinidae & Narcine brasiliensis & Praia de Jacumã, Conde & $\mathrm{PB}$ & Brazil & & & 3 \\
\hline 2788 & Rhinobatidae & Pseudobatos percellens & Praia de Lucena, Lucena & $\mathrm{PB}$ & Brazil & & & 1 \\
\hline 2789 & Rhinobatidae & Pseudobatos percellens & Praia de Lucena, Lucena & $\mathrm{PB}$ & Brazil & & & 1 \\
\hline 2790 & Dasyatidae & Hypanus marianae & Praia de Lucena, Lucena & $\mathrm{PB}$ & Brazil & & & 1 \\
\hline 2845 & Potamotrygonidae & Potamotrygon schroederi & Alto Rio Negro & AM & Brazil & & & 1 \\
\hline 2884 & Carcharhinidae & Carcharhinus plumbeus & Costa da Paraíba & $\mathrm{PB}$ & Brazil & $07^{\circ} 02.24^{\prime} \mathrm{S}$ & $34^{\circ} 33.64^{\prime} \mathrm{W}$ & 1 \\
\hline 2923 & Carcharhinidae & Carcharhinus plumbeus & Costa da Paraíba & $\mathrm{PB}$ & Brazil & $06^{\circ} 48.000^{\prime} \mathrm{S}$ & $34^{\circ} 37.658^{\prime} \mathrm{W}$ & 1 \\
\hline 2924 & Carcharhinidae & Carcharhinus plumbeus & Costa da Paraíba & $\mathrm{PB}$ & Brazil & $06^{\circ} 47.631^{\prime} S$ & $34^{\circ} 38.679^{\prime} \mathrm{W}$ & 1 \\
\hline 2925 & Carcharhinidae & Galeocerdo cuvier & Costa da Paraíba & $\mathrm{PB}$ & Brazil & $06^{\circ} 54.821$ 'S & $34^{\circ} 39 \cdot 980^{\prime} \mathrm{W}$ & 1 \\
\hline
\end{tabular}




\begin{tabular}{|c|c|c|c|c|c|c|c|c|}
\hline $\mathrm{CN}$ & Family & $\begin{array}{c}\text { Taxon } \\
\text { (full name) }\end{array}$ & Locality & $\mathbf{S}$ & Country & Latitude & Longitude & C \\
\hline 2928 & Carcharhinidae & Carcharhinus plumbeus & Costa da Paraíba & $\mathrm{PB}$ & Brazil & $07^{\circ} 02.24^{\prime} \mathrm{S}$ & $34^{\circ} 33.64^{\prime} \mathrm{W}$ & 1 \\
\hline 2929 & Carcharhinidae & Galeocerdo cuvier & Costa da Paraíba & $\mathrm{PB}$ & Brazil & $06^{\circ} 50.785^{\prime} \mathrm{S}$ & $34^{\circ} 40.395^{\prime} \mathrm{W}$ & 1 \\
\hline 3040 & Gymnuridae & Gymnura micrura & Lucena & $\mathrm{PB}$ & Brazil & & & 1 \\
\hline 3041 & Gymnuridae & Gymnura micrura & Lucena & PB & Brazil & & & 1 \\
\hline 3042 & Dasyatidae & Hypanus guttatus & Lucena & PB & Brazil & & & 1 \\
\hline 3043 & Dasyatidae & Hypanus guttatus & Lucena & PB & Brazil & & & 1 \\
\hline 3044 & Urotrygonidae & Urotrygon microphthalmum & Lucena & $\mathrm{PB}$ & Brazil & & & 1 \\
\hline 3045 & Gymnuridae & Gymnura micrura & Lucena & PB & Brazil & & & 1 \\
\hline 3046 & Dasyatidae & Hypanus guttatus & Lucena & PB & Brazil & & & 2 \\
\hline 3047 & Dasyatidae & Hypanus guttatus & Lucena & PB & Brazil & & & 1 \\
\hline 3048 & Narcinidae & Narcine bancroftii & Lucena & $\mathrm{PB}$ & Brazil & & & 1 \\
\hline 3049 & Urotrygonidae & Urotrygon microphthalmum & Lucena & PB & Brazil & & & 1 \\
\hline 3050 & Dasyatidae & Hypanus guttatus & Lucena & $\mathrm{PB}$ & Brazil & & & 1 \\
\hline 3051 & Narcinidae & Narcine brasiliensis & Lucena & $\mathrm{PB}$ & Brazil & & & 2 \\
\hline 3052 & Narcinidae & Narcine brasiliensis & Lucena & $\mathrm{PB}$ & Brazil & & & 1 \\
\hline 3053 & Potamotrygonidae & Potamotrygon motoro & Puerto Reconquista, Rio Geronimo, Santa Fe & - & Argentina & & & 1 \\
\hline 3054 & Potamotrygonidae & Potamotrygon motoro & Puerto Reconquista, Rio Geronimo, Santa Fe & - & Argentina & & & 1 \\
\hline 3055 & Potamotrygonidae & Potamotrygon motoro & Puerto Reconquista, Rio Geronimo, Santa Fe & - & Argentina & & & 1 \\
\hline 3249 & Gymnuridae & Gymnura micrura & Lucena & $\mathrm{PB}$ & Brazil & & & 1 \\
\hline 3250 & Urotrygonidae & Urotrygon microphthalmum & Lucena & $\mathrm{PB}$ & Brazil & & & 1 \\
\hline 3251 & Urotrygonidae & Urotrygon microphthalmum & Lucena & $\mathrm{PB}$ & Brazil & & & 1 \\
\hline 3252 & Narcinidae & Narcine brasiliensis & Lucena & $\mathrm{PB}$ & Brazil & & & 1 \\
\hline 3253 & Dasyatidae & Hypanus guttatus & Lucena & PB & Brazil & & & 1 \\
\hline 3254 & Dasyatidae & Hypanus guttatus & Lucena & $\mathrm{PB}$ & Brazil & & & 1 \\
\hline 3255 & Narcinidae & Narcine brasiliensis & Lucena & PB & Brazil & & & 1 \\
\hline 3256 & Dasyatidae & Hypanus guttatus & Lucena & $\mathrm{PB}$ & Brazil & & & 1 \\
\hline 3283 & Dasyatidae & Hypanus marianae & Praia de Tabatinga, Conde & PB & Brazil & & & 1 \\
\hline 3305 & Carcharhinidae & Rhizoprionodon porosus & Praia de Tambaú & PB & Brazil & & & 1 \\
\hline
\end{tabular}




\begin{tabular}{|c|c|c|c|c|c|c|c|c|}
\hline $\mathrm{CN}$ & Family & $\begin{array}{c}\text { Taxon } \\
\text { (full name) }\end{array}$ & Locality & $\mathbf{S}$ & Country & Latitude & Longitude & C \\
\hline 3306 & Carcharhinidae & Rhizoprionodon porosus & Praia de Tambaú & PB & Brazil & & & 1 \\
\hline 3307 & Carcharhinidae & Carcharhinus acronotus & Cabedelo & $\mathrm{PB}$ & Brazil & & & 1 \\
\hline 3308 & Scyliorhinidae & Scyliorhinus haeckeli & Praia de Tambaú & PB & Brazil & & & 1 \\
\hline 3309 & Carcharhinidae & Rhizoprionodon porosus & Praia de Tambaú & $\mathrm{PB}$ & Brazil & & & 1 \\
\hline 3310 & Carcharhinidae & Rhizoprionodon porosus & Praia de Tambaú & $\mathrm{PB}$ & Brazil & & & 1 \\
\hline 3311 & Carcharhinidae & Rhizoprionodon porosus & Barra de Gramame & $\mathrm{PB}$ & Brazil & & & 1 \\
\hline 3312 & Carcharhinidae & Rhizoprionodon porosus & Praia de Jacumã, Conde & $\mathrm{PB}$ & Brazil & & & 1 \\
\hline 3313 & Carcharhinidae & Rhizoprionodon porosus & Cabedelo & $\mathrm{PB}$ & Brazil & & & 1 \\
\hline 3314 & Carcharhinidae & Rhizoprionodon porosus & Cabedelo & $\mathrm{PB}$ & Brazil & & & 6 \\
\hline 3320 & Urotrygonidae & Urotrygon microphthalmum & Cabedelo & $\mathrm{PB}$ & Brazil & & & 1 \\
\hline 3467 & Potamotrygonidae & Potamotrygon motoro & $\begin{array}{l}\text { Igarapé Cururú, Cachoeira do Arari, Rio Arari, } \\
\text { Ilha de Marajó }\end{array}$ & PA & Brazil & & & 1 \\
\hline 3468 & Potamotrygonidae & Potamotrygon scobina & $\begin{array}{l}\text { Igarapé Cururú, Cachoeira do Arari, Rio Arari, } \\
\text { Ilha de Marajó }\end{array}$ & PA & Brazil & & & 1 \\
\hline 3469 & Potamotrygonidae & Potamotrygon humerosa & $\begin{array}{l}\text { Igarapé Cururú, Cachoeira do Arari, Rio Arari, } \\
\text { Ilha de Marajó }\end{array}$ & PA & Brazil & & & 1 \\
\hline 3470 & Potamotrygonidae & Potamotrygon humerosa & $\begin{array}{l}\text { Igarapé Cururú, Cachoeira do Arari, Rio Arari, } \\
\text { Ilha de Marajó }\end{array}$ & PA & Brazil & & & 1 \\
\hline 3471 & Potamotrygonidae & Potamotrygon motoro & $\begin{array}{l}\text { Igarapé Salito, Cachoeira do Arari, Rio Arari, Ilha } \\
\text { de Marajó }\end{array}$ & PA & Brazil & & & 1 \\
\hline 3472 & Potamotrygonidae & Potamotrygon sp. & $\begin{array}{l}\text { Igarapé Salito, Cachoeira do Arari, Rio Arari, Ilha } \\
\text { de Marajó }\end{array}$ & PA & Brazil & & & 1 \\
\hline 3473 & Potamotrygonidae & Potamotrygon humerosa & $\begin{array}{l}\text { Igarapé Salito, Cachoeira do Arari, Rio Arari, Ilha } \\
\text { de Marajó }\end{array}$ & PA & Brazil & & & 1 \\
\hline 3474 & Potamotrygonidae & Potamotrygon humerosa & $\begin{array}{l}\text { Igarapé Salito, Cachoeira do Arari, Rio Arari, Ilha } \\
\text { de Marajó }\end{array}$ & PA & Brazil & & & 1 \\
\hline 3475 & Potamotrygonidae & Potamotrygon humerosa & $\begin{array}{l}\text { Igarapé Salito, Cachoeira do Arari, Rio Arari, Ilha } \\
\text { de Marajó }\end{array}$ & PA & Brazil & & & 1 \\
\hline 3476 & Potamotrygonidae & Potamotrygon orbignyi & $\begin{array}{l}\text { Igarapé Salito, Cachoeira do Arari, Rio Arari, Ilha } \\
\text { de Marajó }\end{array}$ & PA & Brazil & & & 1 \\
\hline
\end{tabular}




\begin{tabular}{|c|c|c|c|c|c|c|c|c|}
\hline $\mathrm{CN}$ & Family & $\begin{array}{c}\text { Taxon } \\
\text { (full name) }\end{array}$ & Locality & $\mathbf{S}$ & Country & Latitude & Longitude & C \\
\hline 3477 & Potamotrygonidae & Potamotrygon humerosa & $\begin{array}{l}\text { Igarapé Salito, Cachoeira do Arari, Rio Arari, Ilha } \\
\text { de Marajó }\end{array}$ & PA & Brazil & & & 1 \\
\hline 3478 & Potamotrygonidae & Paratrygon aiereba & Cachoeira do Arari, Rio Arari, Ilha de Marajó & PA & Brazil & & & 1 \\
\hline 3479 & Potamotrygonidae & Paratrygon aiereba & Cachoeira do Arari, Rio Arari, Ilha de Marajó & PA & Brazil & & & 1 \\
\hline 3480 & Potamotrygonidae & Potamotrygon scobina & Cachoeira do Arari, Rio Arari, Ilha de Marajó & PA & Brazil & & & 1 \\
\hline 3481 & Potamotrygonidae & Potamotrygon humerosa & Cachoeira do Arari, Rio Arari, Ilha de Marajó & PA & Brazil & & & 1 \\
\hline 3482 & Potamotrygonidae & Potamotrygon sp. & Cachoeira do Arari, Rio Arari, Ilha de Marajó & PA & Brazil & & & 1 \\
\hline 3483 & Potamotrygonidae & Potamotrygon humerosa & Cachoeira do Arari, Rio Arari, Ilha de Marajó & PA & Brazil & & & 1 \\
\hline 3484 & Dasyatidae & Hypanus guttatus & Praia de Lucena, Lucena & PB & Brazil & $0^{\circ} 53^{\prime} \mathrm{S}$ & $34^{\circ} 52^{\prime} \mathrm{W}$ & 1 \\
\hline 3485 & Dasyatidae & Hypanus guttatus & Praia de Lucena, Lucena & PB & Brazil & & & 1 \\
\hline 3486 & Dasyatidae & Hypanus guttatus & Praia de Lucena, Lucena & PB & Brazil & & & 1 \\
\hline 3487 & Dasyatidae & Hypanus guttatus & Praia de Lucena, Lucena & PB & Brazil & $\mathrm{oo}^{\circ} 53^{\prime} \mathrm{S}$ & $34^{\circ} 5^{\prime} \mathrm{W}$ & 1 \\
\hline 3488 & Gymnuridae & Gymnura micrura & Praia de Lucena, Lucena & PB & Brazil & $0^{\circ} 53^{\prime} \mathrm{S}$ & $34^{\circ} 5^{\prime} \mathrm{W}$ & 1 \\
\hline 3513 & Dasyatidae & Hypanus americanus & Naufrágio Queimado, João Pessoa & PB & Brazil & $07^{\circ} 05^{\prime} \mathrm{S}$ & $35^{\circ} 44^{\prime} \mathrm{W}$ & 3 \\
\hline 3515 & Potamotrygonidae & Potamotrygon orbignyi & Cachoeira do Arari, Rio Arari, Ilha de Marajó & PA & Brazil & & & 1 \\
\hline 3516 & Potamotrygonidae & Potamotrygon humerosa & Cachoeira do Arari, Rio Arari, Ilha de Marajó & PA & Brazil & & & 1 \\
\hline 3517 & Potamotrygonidae & Potamotrygon orbignyi & Cachoeira do Arari, Rio Arari, Ilha de Marajó & PA & Brazil & & & 1 \\
\hline 3518 & Potamotrygonidae & Potamotrygon humerosa & Cachoeira do Arari, Rio Arari, Ilha de Marajó & PA & Brazil & & & 1 \\
\hline 3519 & Potamotrygonidae & Potamotrygon orbignyi & Cachoeira do Arari, Rio Arari, Ilha de Marajó & PA & Brazil & & & 1 \\
\hline 3520 & Potamotrygonidae & Potamotrygon humerosa & $\begin{array}{l}\text { Praia Malhada, Cachoeira do Arari, Rio Arari, Ilha } \\
\text { de Marajó }\end{array}$ & PA & Brazil & & & 1 \\
\hline 3521 & Potamotrygonidae & Potamotrygon orbignyi & Joroca, Rio Tocantins, Cametá & PA & Brazil & & & 1 \\
\hline 3522 & Potamotrygonidae & Potamotrygon motoro & Joroca, Rio Tocantins, Cametá & PA & Brazil & & & 1 \\
\hline 3523 & Potamotrygonidae & Potamotrygon limai & Joroca, Rio Tocantins, Cametá & PA & Brazil & & & 1 \\
\hline 3524 & Potamotrygonidae & Paratrygon aiereba & $\begin{array}{l}\text { Praia Malhada,Cachoeira do Arari, Rio Arari, Ilha } \\
\text { de Marajó }\end{array}$ & PA & Brazil & & & 1 \\
\hline 3525 & Potamotrygonidae & Potamotrygon humerosa & $\begin{array}{l}\text { Praia Malhada,Cachoeira do Arari, Rio Arari, Ilha } \\
\text { de Marajó }\end{array}$ & PA & Brazil & & & 1 \\
\hline
\end{tabular}




\begin{tabular}{|c|c|c|c|c|c|c|c|c|}
\hline $\mathrm{CN}$ & Family & $\begin{array}{c}\text { Taxon } \\
\text { (full name) }\end{array}$ & Locality & S & Country & Latitude & Longitude & C \\
\hline 3526 & Potamotrygonidae & Potamotrygon motoro & $\begin{array}{l}\text { Praia Malhada,Cachoeira do Arari, Rio Arari, Ilha } \\
\text { de Marajó }\end{array}$ & $\mathrm{PA}$ & Brazil & & & 1 \\
\hline 3527 & Potamotrygonidae & Potamotrygon humerosa & $\begin{array}{l}\text { Praia Malhada,Cachoeira do Arari, Rio Arari, Ilha } \\
\text { de Marajó }\end{array}$ & PA & Brazil & & & 1 \\
\hline 3528 & Potamotrygonidae & Potamotrygon humerosa & $\begin{array}{l}\text { Praia Malhada,Cachoeira do Arari, Rio Arari, Ilha } \\
\text { de Marajó }\end{array}$ & PA & Brazil & & & - \\
\hline 3529 & Potamotrygonidae & Potamotrygon orbignyi & $\begin{array}{l}\text { Praia Malhada,Cachoeira do Arari, Rio Arari, Ilha } \\
\text { de Marajó }\end{array}$ & PA & Brazil & & & \\
\hline 3530 & Potamotrygonidae & Potamotrygon humerosa & $\begin{array}{l}\text { Praia Malhada,Cachoeira do Arari, Rio Arari, Ilha } \\
\text { de Marajó }\end{array}$ & PA & Brazil & & & 1 \\
\hline 3531 & Potamotrygonidae & Potamotrygon orbignyi & $\begin{array}{l}\text { Praia Malhada,Cachoeira do Arari, Rio Arari, Ilha } \\
\text { de Marajó }\end{array}$ & PA & Brazil & & & 1 \\
\hline 3532 & Potamotrygonidae & Potamotrygon falkneri & Rio Guamá, Ourém & PA & Brazil & & & 1 \\
\hline 3533 & Potamotrygonidae & Paratrygon aiereba & Ilha Guariba, Rio Negro & $\mathrm{AM}$ & Brazil & $01^{\circ} 21^{\prime} 51^{\prime \prime S}$ & $61^{\circ} 47^{\prime} 34^{\prime \prime} \mathrm{W}$ & 1 \\
\hline 3534 & Potamotrygonidae & Paratrygon aiereba & Ilha Guariba, Rio Negro & $\mathrm{AM}$ & Brazil & $01^{\circ} 21^{\prime} 51^{\prime \prime S}$ & $61^{\circ} 47^{\prime} 34^{\prime \prime} \mathrm{W}$ & 1 \\
\hline 3535 & Potamotrygonidae & Paratrygon aiereba & Ilha em frente ao Igarapé Corimbaú, Rio Branco & $\mathrm{AM}$ & Brazil & & & 1 \\
\hline 3536 & Potamotrygonidae & Potamotrygon orbignyi & Ilha em frente ao Igarapé Corimbaú, Rio Branco & $\mathrm{AM}$ & Brazil & & & 1 \\
\hline 3537 & Potamotrygonidae & Potamotrygon orbignyi & Ilha Guariba, Rio Negro & $\mathrm{AM}$ & Brazil & $\mathrm{O}^{\circ} 21^{\prime} 51^{\prime \prime S}$ & $61^{\circ} 47^{\prime} 34^{\prime \prime} \mathrm{W}$ & 1 \\
\hline 3538 & Potamotrygonidae & Potamotrygon orbignyi & Praia do Defunto, Rio Negro, acima de Barcelos & $\mathrm{AM}$ & Brazil & & & 1 \\
\hline 3539 & Potamotrygonidae & Potamotrygon orbignyi & Praia do Defunto, Rio Negro & $\mathrm{AM}$ & Brazil & & & 1 \\
\hline 3540 & Potamotrygonidae & Plesiotrygon iwamae & Paraná Janamaca, Rio Solimões & $\mathrm{AM}$ & Brazil & & & 1 \\
\hline 3541 & Potamotrygonidae & Potamotrygon motoro & Paraná Janamaca, Rio Solimões & AM & Brazil & & & 1 \\
\hline 3542 & Potamotrygonidae & Potamotrygon scobina & Paraná Janamaca, Rio Solimões & AM & Brazil & & & 1 \\
\hline 3543 & Potamotrygonidae & Potamotrygon wallacei & Barcelos, Rio Negro & $\mathrm{AM}$ & Brazil & & & 1 \\
\hline 3544 & Potamotrygonidae & Potamotrygon sp. & Altamira, Rio Xingu & PA & Brazil & & & - \\
\hline 3546 & Potamotrygonidae & Potamotrygon signata & $\begin{array}{l}\text { Rio Poti na confluência com Rio Parnaíba, } \\
\text { Teresina }\end{array}$ & PI & Brazil & & & 2 \\
\hline 3734 & Dasyatidae & Hypanus guttatus & $\begin{array}{l}\text { Rio Mamanguape, Barra de Mamanguape, Rio } \\
\text { Tinto }\end{array}$ & $\mathrm{PB}$ & Brazil & & & 1 \\
\hline
\end{tabular}




\begin{tabular}{|c|c|c|c|c|c|c|c|c|}
\hline $\mathrm{CN}$ & Family & $\begin{array}{l}\text { Taxon } \\
\text { (full name) }\end{array}$ & Locality & $\mathbf{S}$ & Country & Latitude & Longitude & $\mathrm{C}$ \\
\hline 3735 & Gymnuridae & Gymnura micrura & $\begin{array}{l}\text { Rio Mamanguape, Barra de Mamanguape, Rio } \\
\text { Tinto }\end{array}$ & $\mathrm{PB}$ & Brazil & & & 1 \\
\hline 3823 & Narcinidae & Narcine brasiliensis & $\begin{array}{l}\text { Rio Mamanguape, Barra de Mamanguape, Rio } \\
\text { Tinto }\end{array}$ & $\mathrm{PB}$ & Brazil & & & 1 \\
\hline 3824 & Gymnuridae & Gymnura micrura & $\begin{array}{l}\text { Rio Mamanguape, Barra de Mamanguape, Rio } \\
\text { Tinto }\end{array}$ & $\mathrm{PB}$ & Brazil & & & 1 \\
\hline 4204 & Carcharhinidae & Carcharhinus perezii & Parcel Manoel Luiz & MA & Brazil & & & 3 \\
\hline 4238 & Dasyatidae & Hypanus marianae & $\begin{array}{l}\text { Costa da Paraíba, Oceano Atlântico, Naufrágio } \\
\text { Alice, João Pessoa }\end{array}$ & $\mathrm{PB}$ & Brazil & & & 1 \\
\hline 4239 & Aetobatidae & Aetobatus narinari & Praia da Penha, João Pessoa & $\mathrm{PB}$ & Brazil & & & 1 \\
\hline 4750 & Dasyatidae & Hypanus guttatus & $\begin{array}{l}\text { Rio Mamanguape, estuário próximo a gamboa do } \\
\text { macaço, Rio Tinto }\end{array}$ & PI & Brazil & & & 1 \\
\hline 4758 & Dasyatidae & Hypanus marianae & Trebaúma & $\mathrm{BA}$ & Brazil & & & 1 \\
\hline 4780 & Dasyatidae & Hypanus guttatus & Subaúma & $\mathrm{BA}$ & Brazil & & & 1 \\
\hline 4810 & Sphyrnidae & Sphyrna lewini & Poças, Conde & BA & Brazil & & & 1 \\
\hline 4811 & Carcharhinidae & Carcharhinus acronotus & Poças, Conde & $\mathrm{BA}$ & Brazil & & & 1 \\
\hline 4827 & Carcharhinidae & Rhizoprionodon lalandii & Poças, Conde & BA & Brazil & & & 1 \\
\hline 4865 & Potamotrygonidae & Potamotrygon wallacei & Rio Itú, afluente do Rio Negro, Barcelos & AM & Brazil & $\mathrm{oo}^{\circ} 56^{\prime} \mathrm{S}$ & $62^{\circ} 54^{\prime} \mathrm{W}$ & 36 \\
\hline 4866 & Potamotrygonidae & Potamotrygon wallacei & Rio Itú, afluente do Rio Negro, Barcelos & AM & Brazil & $0^{\circ} 56 \mathrm{~S}$ & $62^{\circ} 54^{\prime} \mathrm{W}$ & 1 \\
\hline 4867 & Potamotrygonidae & Potamotrygon wallacei & Rio Itú, afluente do Rio Negro, Barcelos & AM & Brazil & $0^{\circ} 56^{\prime} \mathrm{S}$ & $62^{\circ} 54^{\prime} \mathrm{W}$ & 1 \\
\hline 5214 & Potamotrygonidae & Potamotrygon wallacei & $\begin{array}{l}\text { Igarapé Zamula, afluente do Rio Negro, } 20 \text { km } \\
\text { abaixo de Barcelos }\end{array}$ & AM & Brazil & $\mathrm{oo}^{\circ} \mathrm{O} 55^{\prime} \mathrm{s}$ & $62^{\circ} 46{ }^{\prime} 1^{\prime \prime W}$ & 4 \\
\hline 5215 & Potamotrygonidae & Potamotrygon wallacei & $\begin{array}{l}\text { Rio Itú, afluente do Rio Negro, ca.7okm acima de } \\
\text { Barcelos }\end{array}$ & AM & Brazil & $\mathrm{Oo}^{\circ} 28^{\prime} 39^{\prime \prime S}$ & $63^{\circ} 15^{\prime} 30^{\prime \prime} \mathrm{W}$ & 3 \\
\hline 5216 & Potamotrygonidae & Potamotrygon wallacei & $\begin{array}{l}\text { Rio Itú, afluente do Rio Negro, ca.7okm acima de } \\
\text { Barcelos }\end{array}$ & AM & Brazil & $\mathrm{oo}^{\circ} 28^{\prime} 39^{\prime \prime S}$ & $63^{\circ} 15^{\prime} 30^{\prime \prime} \mathrm{W}$ & 1 \\
\hline 5217 & Potamotrygonidae & Potamotrygon wallacei & $\begin{array}{l}\text { Rio Itú, afluente do Rio Negro, ca.7okm acima de } \\
\text { Barcelos }\end{array}$ & AM & Brazil & $\mathrm{Oo}^{\circ} 28^{\prime} 39^{\prime \prime} \mathrm{S}$ & $63^{\circ} 15^{\prime} 30^{\prime \prime} \mathrm{W}$ & 1 \\
\hline 5218 & Gymnuridae & Gymnura micrura & Praia do Amor, Jacumã, Conde & $\mathrm{PB}$ & Brazil & $07^{\circ} 16^{\prime} 24,4$ "S & $34^{\circ} 5^{\prime} 19,3^{\prime \prime} \mathrm{W}$ & 1 \\
\hline 5219 & Dasyatidae & Hypanus marianae & Praia do Amor, Jacumã, Conde & PB & Brazil & $07^{\circ} 16^{\prime} 24,4$ "S & $34^{\circ} 5^{\prime} 19,3^{\prime \prime} \mathrm{W}$ & 1 \\
\hline
\end{tabular}




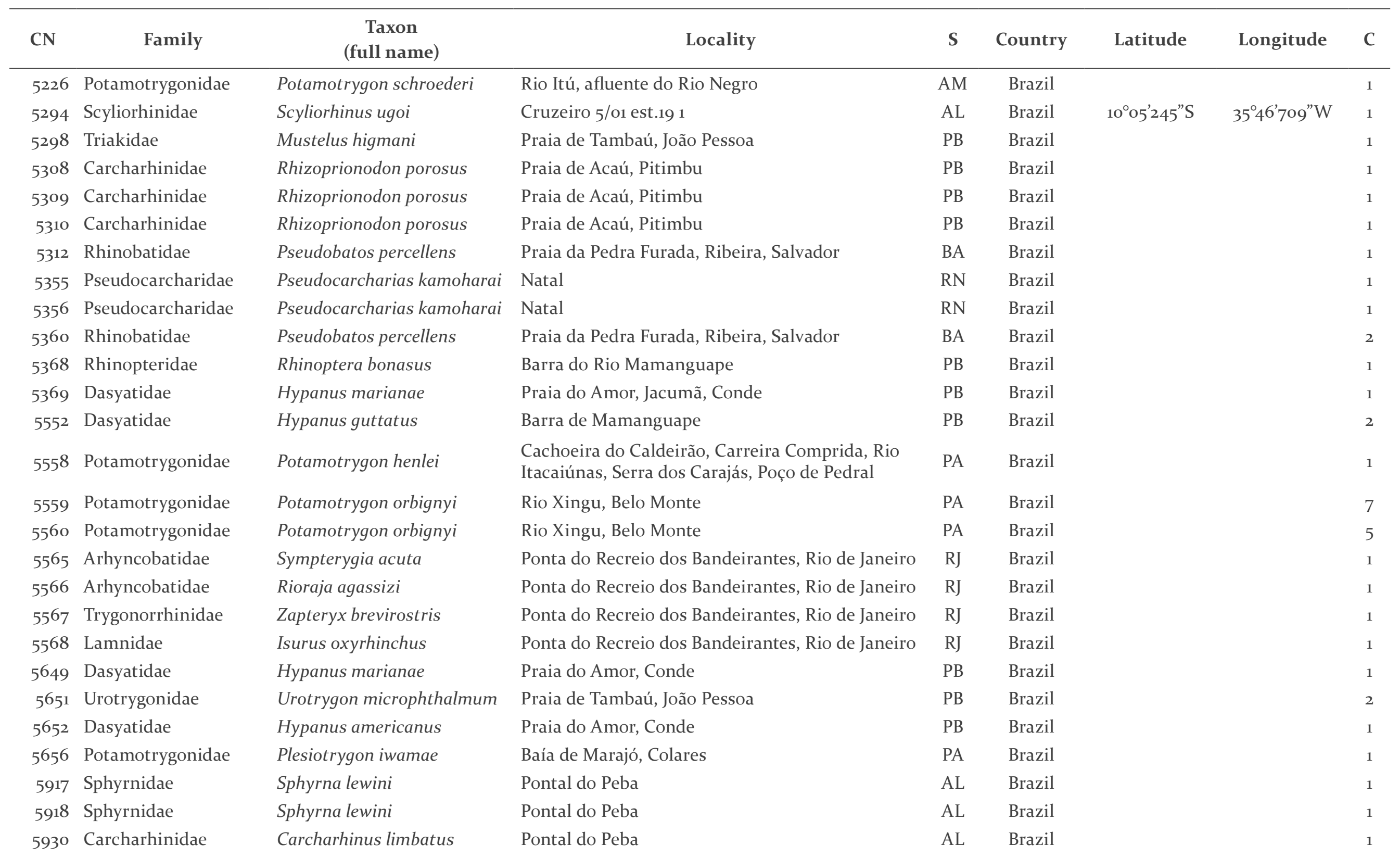




\begin{tabular}{|c|c|c|c|c|c|c|c|c|}
\hline $\mathrm{CN}$ & Family & $\begin{array}{l}\text { Taxon } \\
\text { (full name) }\end{array}$ & Locality & $\mathbf{S}$ & Country & Latitude & Longitude & C \\
\hline 5931 & Carcharhinidae & Carcharhinus limbatus & Pontal do Peba & $\mathrm{AL}$ & Brazil & & & 1 \\
\hline 5932 & Triakidae & Mustelus canis & Pontal do Peba & $\mathrm{AL}$ & Brazil & & & 1 \\
\hline 5933 & Carcharhinidae & Carcharhinus limbatus & Pontal do Peba & $\mathrm{AL}$ & Brazil & & & 1 \\
\hline 5934 & Carcharhinidae & Carcharhinus limbatus & Pontal do Peba & $\mathrm{AL}$ & Brazil & & & 1 \\
\hline 5935 & Carcharhinidae & Carcharhinus limbatus & Pontal do Peba & AL & Brazil & & & 1 \\
\hline 5936 & Rhinobatidae & Pseudobatos percellens & Praia do Amor, Conde & $\mathrm{PB}$ & Brazil & & & 1 \\
\hline 5964 & Carcharhinidae & Rhizoprionodon porosus & Praia do Amor, Jacumã, Conde & $\mathrm{PB}$ & Brazil & $07^{\circ} 16_{24,4}^{\prime} \mathrm{S}$ & $34^{\circ} 5^{\prime} 19,3 ” \mathrm{~W}$ & 1 \\
\hline 5965 & Rhinobatidae & Pseudobatos percellens & Praia do Amor, Jacumã, Conde & $\mathrm{PB}$ & Brazil & $07^{\circ} 16^{\prime} 24,4^{\prime \prime S}$ & $34^{\circ} 58^{\prime} 19,3^{\prime \prime W}$ & 1 \\
\hline 5966 & Rhinobatidae & Pseudobatos percellens & Praia da Ribeira, Salvador & BA & Brazil & & & 1 \\
\hline 5986 & Aetobatidae & Aetobatus narinari & Praia de Campina, Município de Rio Tinto & $\mathrm{PB}$ & Brazil & & & 1 \\
\hline 5987 & Narcinidae & Narcine brasiliensis & Praia do Amor, Jacumã, Conde & $\mathrm{PB}$ & Brazil & $07^{\circ} 16_{24,4}^{\prime} \mathrm{S}$ & $34^{\circ} 58^{\prime} 19,3 ” \mathrm{~W}$ & 1 \\
\hline 5988 & Rhinobatidae & Pseudobatos percellens & Praia do Amor, Jacumã, Conde & $\mathrm{PB}$ & Brazil & $07^{0} 16_{24,4}^{\prime \prime S}$ & $34^{\circ} 58^{\prime} 19,3 ” \mathrm{~W}$ & 1 \\
\hline 6033 & Gymnuridae & Gymnura micrura & Praia de Manaíra, João Pessoa & $\mathrm{PB}$ & Brazil & $07^{\circ} 06_{2}^{\prime} 8,8^{\prime \prime} \mathrm{S}$ & $34^{\circ} 499^{\prime} 30,1 ” W$ & 1 \\
\hline 6034 & Gymnuridae & Gymnura micrura & Praia de Manaíra, João Pessoa & $\mathrm{PB}$ & Brazil & & & 1 \\
\hline 6035 & Carcharhinidae & Rhizoprionodon porosus & Praia de Manaíra, João Pessoa & $\mathrm{PB}$ & Brazil & & & 1 \\
\hline 6042 & Dasyatidae & Hypanus americanus & $\begin{array}{l}\text { Naufrágio Pirapama, Oceano Atlântico, costa de } \\
\text { Pernambuco }\end{array}$ & $\mathrm{PE}$ & Brazil & o8 ${ }^{\circ} \mathrm{o} 3^{\prime} \mathrm{S}$ & $34^{\circ} 46^{\prime} \mathrm{W}$ & 1 \\
\hline 6075 & Carcharhinidae & Rhizoprionodon porosus & Praia do Amor, Jacumã, Conde & $\mathrm{PB}$ & Brazil & $07^{\circ} 16_{2}^{\prime} 4,4^{\prime \prime S}$ & $34^{\circ} 58^{\prime} 19,3 ” \mathrm{~W}$ & 3 \\
\hline 6076 & Rhinobatidae & Pseudobatos percellens & Praia do Amor, Jacumã, Conde & $\mathrm{PB}$ & Brazil & $07^{\circ} 16_{24,4}^{\prime} \mathrm{S}$ & $34^{\circ} 58$ ' $19,3 ” \mathrm{~W}$ & 1 \\
\hline 6077 & Gymnuridae & Gymnura micrura & Praia do Amor, Jacumã, Conde & $\mathrm{PB}$ & Brazil & $07^{\circ} 16_{24,4}^{\prime \prime S}$ & $34^{\circ} 58^{\prime} 19,3 ” \mathrm{~W}$ & 1 \\
\hline 6078 & Rhinobatidae & Pseudobatos percellens & Praia do Amor, Jacumã, Conde & $\mathrm{PB}$ & Brazil & $07^{\circ} 16^{\prime} 24,4^{\prime \prime S}$ & $34^{\circ} 58^{\prime} 19,3 ” \mathrm{~W}$ & 1 \\
\hline 6079 & Potamotrygonidae & Potamotrygon sp. & $\begin{array}{l}\text { Lago Arari, Município de Santa Cruz do Arari, } \\
\text { Ilha do Marajó }\end{array}$ & PA & Brazil & $\mathrm{O}^{\circ} 4335,5$ ”S & $48^{\circ} 08^{\prime} 39,1 ” \mathrm{~W}$ & 1 \\
\hline 6080 & Potamotrygonidae & Potamotrygon sp. & $\begin{array}{l}\text { Lago Arari, Município de Santa Cruz do Arari, } \\
\text { Ilha de Marajó }\end{array}$ & PA & Brazil & $\mathrm{O}^{\circ} 42^{\prime} 41,6$ "S & $49^{\circ}$ o9'18,6”W & 1 \\
\hline 6081 & Potamotrygonidae & Potamotrygon orbignyi & Barcelos, Rio Negro & AM & Brazil & & & 1 \\
\hline 6082 & Rhinobatidae & Pseudobatos percellens & Praia do Amor, Jacumã, Conde & $\mathrm{PB}$ & Brazil & $07^{\circ} 16_{24}^{\prime}, 4^{\prime \prime S}$ & $34^{\circ} 58^{\prime} 19,3$ "W & 1 \\
\hline 6083 & Carcharhinidae & Rhizoprionodon porosus & Praia do Amor, Jacumã, Conde & $\mathrm{PB}$ & Brazil & $07^{\circ} 16_{24,4}^{\prime} \mathrm{S}$ & $34^{\circ} 58^{\prime} 19,3 ” \mathrm{~W}$ & 3 \\
\hline 6084 & Ginglymostomatidae & Ginglymostoma cirratum & Praia do Amor, Jacumã, Conde & $\mathrm{PB}$ & Brazil & $07^{\circ} 16_{24,4}^{\prime \prime S}$ & $34^{\circ} 58^{\prime} 19,3 ” \mathrm{~W}$ & 1 \\
\hline
\end{tabular}




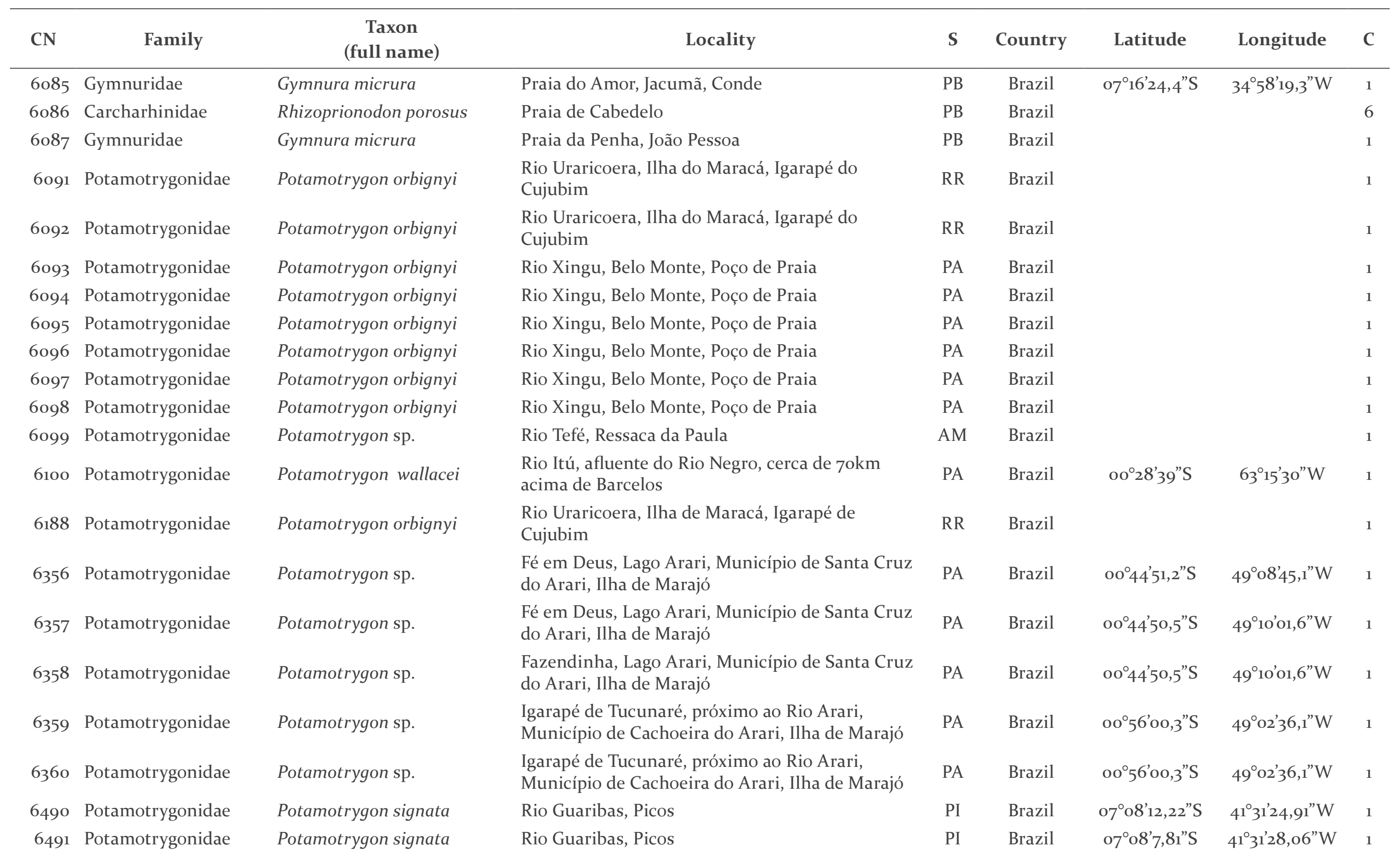




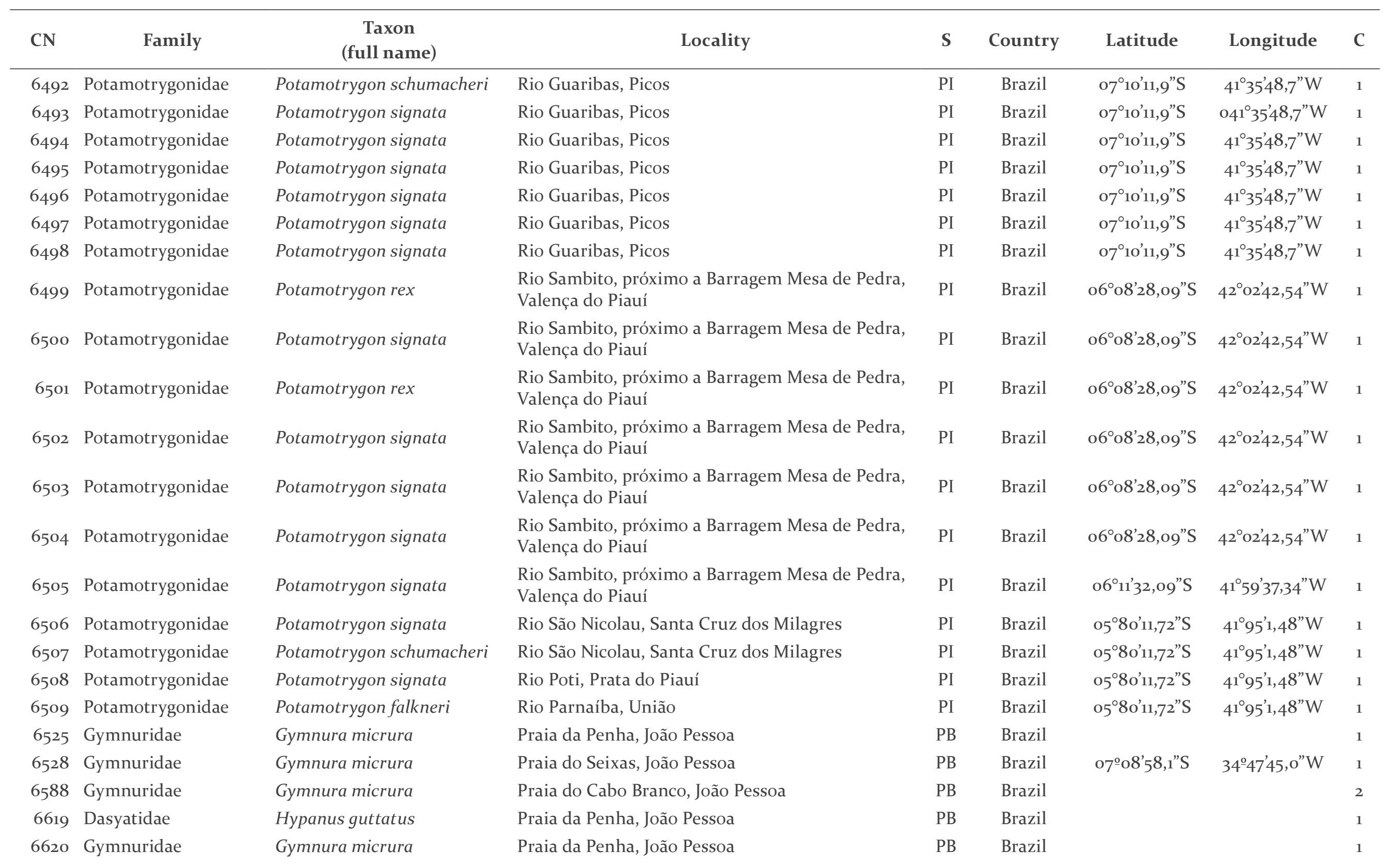




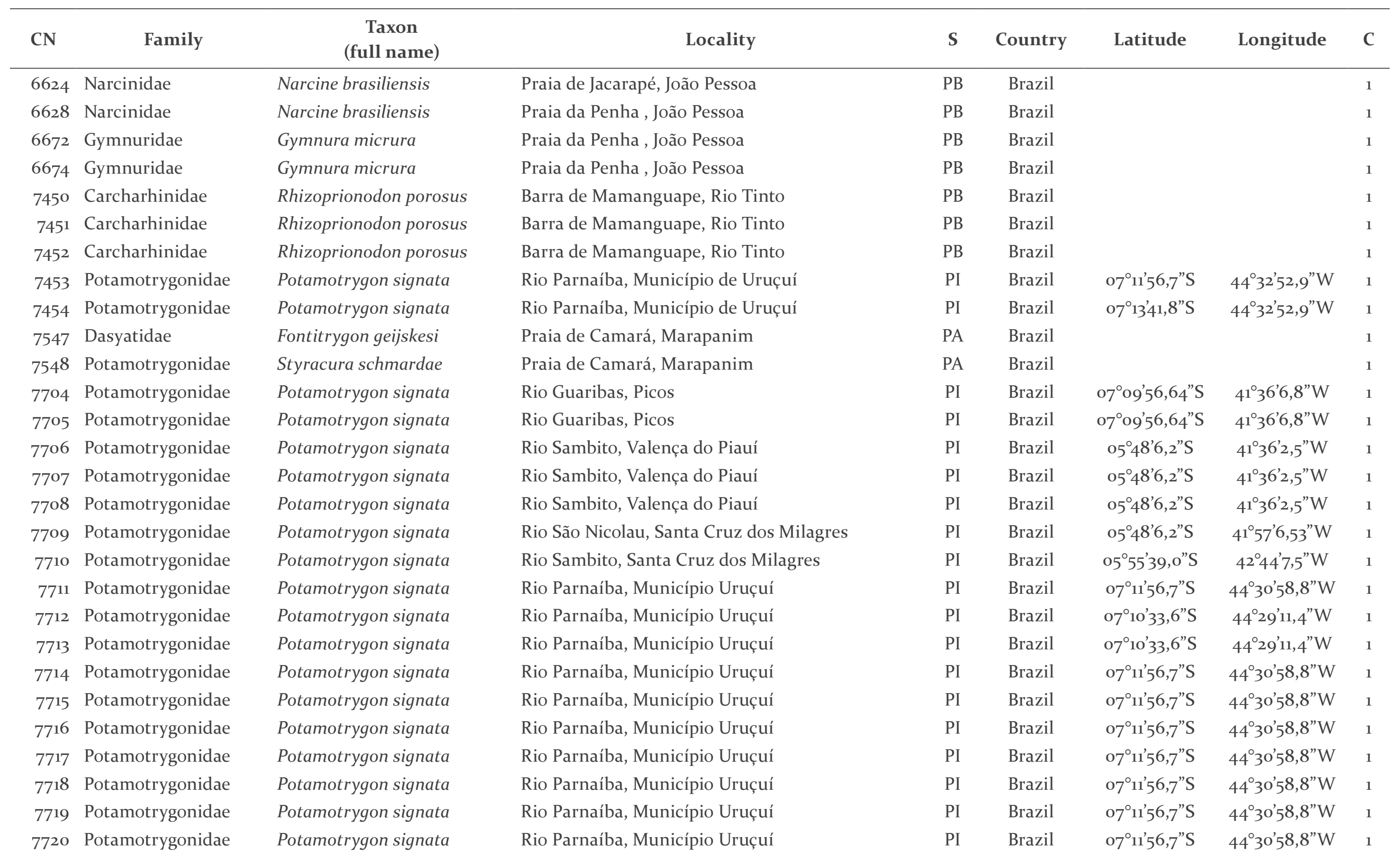




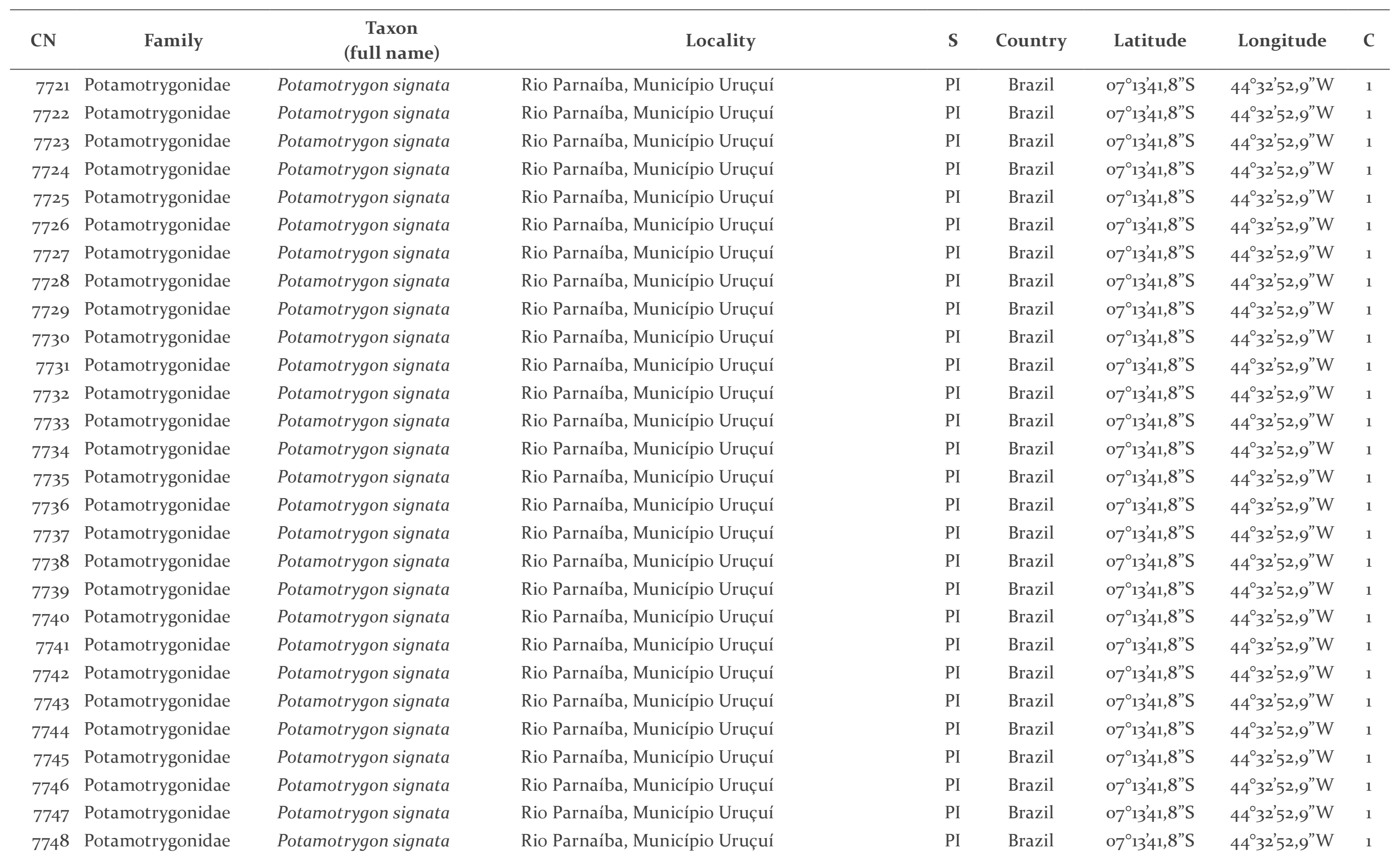




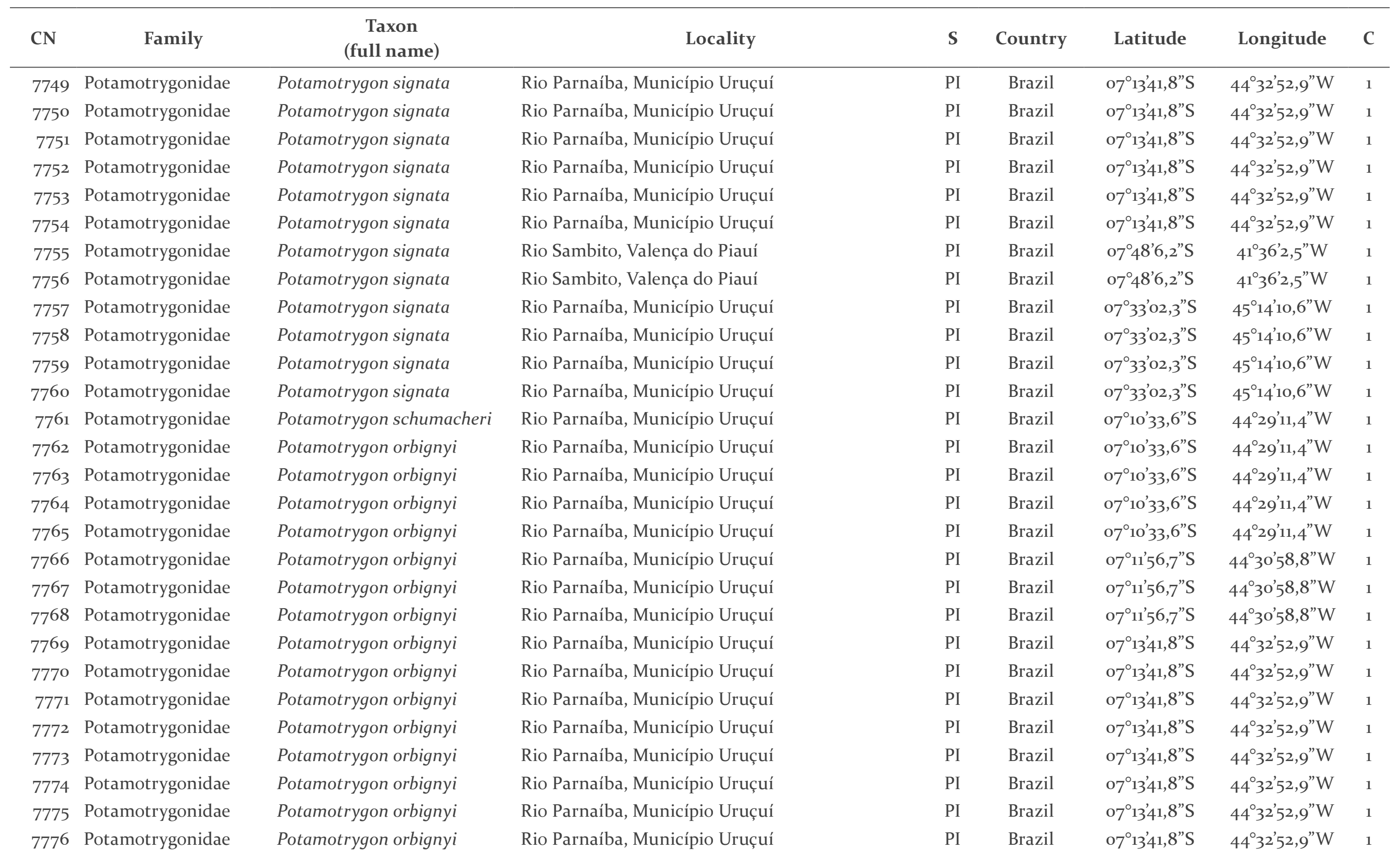




\begin{tabular}{|c|c|c|c|c|c|c|c|c|}
\hline $\mathrm{CN}$ & Family & $\begin{array}{c}\text { Taxon } \\
\text { (full name) }\end{array}$ & Locality & $\mathbf{S}$ & Country & Latitude & Longitude & C \\
\hline 7777 & Potamotrygonidae & Potamotrygon orbignyi & Rio Parnaíba, Município Uruçuí & PI & Brazil & $07^{\circ} 1341,8 ” S$ & $44^{\circ} 32^{\prime} 52,9 ” \mathrm{~W}$ & 1 \\
\hline 7778 & Potamotrygonidae & Potamotrygon orbignyi & Rio Parnaíba, Município Uruçuí & PI & Brazil & $07^{\circ} 13^{\prime} 41,8 ” S$ & $44^{\circ} 32^{\prime} 52,9 " \mathrm{~W}$ & 1 \\
\hline 7779 & Potamotrygonidae & Potamotrygon orbignyi & Rio Parnaíba, Município Uruçuí & PI & Brazil & $07^{\circ} 13^{\prime} 41,8 ” S$ & $44^{\circ} 32^{\prime} 52,9 " \mathrm{~W}$ & 1 \\
\hline 7780 & Potamotrygonidae & Potamotrygon orbignyi & Rio Parnaíba, Município Uruçuí & PI & Brazil & $07^{\circ} 13^{\prime} 41,8 ” S$ & $44^{\circ} 32^{\prime} 52,9 " \mathrm{~W}$ & 1 \\
\hline 7781 & Potamotrygonidae & Potamotrygon orbignyi & Rio Parnaíba, Município Uruçuí & PI & Brazil & $07^{\circ} 13{ }^{\prime} 41,8 ” S$ & $44^{\circ} 32^{\prime} 52,9 ” \mathrm{~W}$ & 1 \\
\hline 7782 & Potamotrygonidae & Potamotrygon orbignyi & Rio Parnaíba, Município Uruçuí & PI & Brazil & $07^{\circ} 13^{\prime} 41,8 ” S$ & $44^{\circ} 32^{\prime} 52,9 " \mathrm{~W}$ & 1 \\
\hline 7783 & Potamotrygonidae & Potamotrygon orbignyi & Rio Parnaíba, Município Uruçuí & PI & Brazil & $07^{\circ} 13^{\prime} 41,8 ” S$ & $44^{\circ} 32^{\prime} 52,9 " \mathrm{~W}$ & 1 \\
\hline 8090 & Potamotrygonidae & Potamotrygon signata & Rio Parnaíba, Povoado Beira Rio, Buriti & MA & Brazil & $03^{\circ} 5339,9 " \mathrm{~S}$ & $42^{\circ} 43^{\prime} 25,7 " \mathrm{~W}$ & 1 \\
\hline 8546 & Potamotrygonidae & Potamotrygon signata & Rio Parnaíba, Povoado Correntes, Caxias & MA & Brazil & $04^{\circ} 33^{\prime} 42,3^{\prime \prime S}$ & $42^{\circ} 52^{\prime} \mathrm{O} 1,8 ” \mathrm{~W}$ & 1 \\
\hline 8547 & Potamotrygonidae & Potamotrygon signata & Rio Parnaíba, Povoado Beira Rio, Buriti & MA & Brazil & $03^{\circ} 53^{\prime} 22,4 ” S$ & $42^{\circ} 43^{\prime} \mathrm{O} 1^{\prime} 25,1^{\prime \prime} \mathrm{W}$ & 1 \\
\hline 9017 & Potamotrygonidae & Potamotrygon wallacei & $\begin{array}{l}\text { Rio Itú, afluente do Rio Negro, ca. } 70 \mathrm{Km} \text { acima de } \\
\text { Barcelos }\end{array}$ & AM & Brazil & $\mathrm{Oo}^{\circ} 28^{\prime} 39^{\prime \prime} \mathrm{S}$ & $63^{\circ} 15^{\prime} 30^{\prime \prime W}$ & 2 \\
\hline 9022 & Carcharhinidae & Rhizoprionodon porosus & Praia de Pitimbu, Pitimbu & $\mathrm{PB}$ & Brazil & & & 1 \\
\hline 9023 & Carcharhinidae & Rhizoprionodon terraenovae & Galveston, Texas & - & USA & & & 4 \\
\hline 9029 & Carcharhinidae & Rhizoprionodon porosus & Praia de Jacumã, Conde & $\mathrm{PB}$ & Brazil & & & 1 \\
\hline 9031 & Carcharhinidae & Carcharhinus porosus & Praia de Camará, Marapanim & PA & Brazil & & & 1 \\
\hline 9032 & Carcharhinidae & Carcharhinus limbatus & Praia de Camará, Marapanim & PA & Brazil & & & 1 \\
\hline 9033 & Rhinobatidae & Pseudobatos percellens & Praia de Lucena, Lucena & $\mathrm{PB}$ & Brazil & & & 1 \\
\hline 9034 & Narcinidae & Narcine brasiliensis & Praia da Penha, João Pessoa & $\mathrm{PB}$ & Brazil & & & 2 \\
\hline 9035 & Narcinidae & Narcine brasiliensis & Praia da Penha, João Pessoa & $\mathrm{PB}$ & Brazil & & & 1 \\
\hline 9036 & Urotrygonidae & Urotrygon microphtalmum & $\begin{array}{l}\text { Praia de Lucena, Lucena, próximo a Foz do Rio } \\
\text { Miriri }\end{array}$ & $\mathrm{PB}$ & Brazil & & & 1 \\
\hline 9037 & Carcharhinidae & Rhizoprionodon porosus & Praia de Tambaú, João Pessoa & $\mathrm{PB}$ & Brazil & & & 1 \\
\hline 9038 & Carcharhinidae & Rhizoprionodon porosus & Praia de Tambaú, João Pessoa & $\mathrm{PB}$ & Brazil & & & 1 \\
\hline 9196 & Dasyatidae & Hypanus cf. americanus & Praia de Camará & PA & Brazil & & & 1 \\
\hline 9197 & Gymnuridae & Gymnura micrura & Praia de Camará, Marapanim & PA & Brazil & oo-34'46,81”S & $47^{\circ} 41^{\prime} \mathrm{O} 1,10^{\prime \prime} \mathrm{W}$ & 1 \\
\hline 9198 & Gymnuridae & Gymnura micrura & Praia de Camará, Marapanim & PA & Brazil & oо-35' 18,79 ”'S & $47^{\circ} 41^{\prime} 17,85^{\prime \prime} \mathrm{W}$ & 1 \\
\hline 9199 & Gymnuridae & Gymnura micrura & Praia de Camará, Marapanim & $\mathrm{PA}$ & Brazil & oo-34'46,81"S & $47^{\circ} 41^{\prime} \mathrm{O}, 10^{\prime \prime} \mathrm{W}$ & 1 \\
\hline 9200 & Gymnuridae & Gymnura micrura & Praia de Camará, Marapanim & PA & Brazil & oо $35^{\prime} 18,79$ ” S & $47^{\circ} 41^{\prime} 17,85^{\prime \prime} \mathrm{W}$ & 1 \\
\hline
\end{tabular}




\begin{tabular}{|c|c|c|c|c|c|c|c|c|}
\hline $\mathrm{CN}$ & Family & $\begin{array}{c}\text { Taxon } \\
\text { (full name) }\end{array}$ & Locality & $\mathbf{S}$ & Country & Latitude & Longitude & C \\
\hline 9201 & Gymnuridae & Gymnura micrura & Praia de Camará, Marapanim & PA & Brazil & oo-35'18,79”S & $47^{\circ} 41^{\prime} 17,85^{\prime \prime} \mathrm{W}$ & 1 \\
\hline 9202 & Gymnuridae & Gymnura micrura & Praia de Camará, Marapanim & PA & Brazil & oo-34'46,81"S & $47^{\circ} 41^{\prime} 01,10^{\prime \prime W}$ & 1 \\
\hline 9203 & Gymnuridae & Gymnura micrura & Praia de Camará, Marapanim & $\mathrm{PA}$ & Brazil & oo 3447,76 ”S & $47^{\circ} 40^{\prime} 59,19^{\prime \prime} \mathrm{W}$ & 1 \\
\hline 9204 & Gymnuridae & Gymnura micrura & Praia de Camará, Marapanim & PA & Brazil & oo $3447,76 ” S$ & $47^{\circ} 40^{\prime} 59,19 ” \mathrm{~W}$ & 1 \\
\hline 9205 & Gymnuridae & Gymnura micrura & Praia de Camará, Marapanim & PA & Brazil & $\mathrm{oo}^{\circ} 344^{\prime} 6,81 " \mathrm{~S}$ & $47^{\circ} 41^{\prime} 01,10^{\prime \prime W}$ & 1 \\
\hline 9206 & Gymnuridae & Gymnura micrura & Praia de Camará, Marapanim & PA & Brazil & oo 34 ' 18,79 ”S & $47^{\circ} 41^{\prime} 17,85^{\prime \prime} \mathrm{W}$ & 1 \\
\hline 9207 & Gymnuridae & Gymnura micrura & Praia de Camará, Marapanim & PA & Brazil & & & 1 \\
\hline 9208 & Gymnuridae & Gymnura micrura & Praia de Camará, Marapanim & PA & Brazil & & & 1 \\
\hline 9209 & Gymnuridae & Gymnura micrura & Praia de Camará, Marapanim & $\mathrm{PA}$ & Brazil & & & 1 \\
\hline 9210 & Gymnuridae & Gymnura micrura & Praia de Camará, Marapanim & PA & Brazil & & & 1 \\
\hline 9211 & Gymnuridae & Gymnura micrura & Praia de Camará, Marapanim & PA & Brazil & & & 1 \\
\hline 9212 & Gymnuridae & Gymnura micrura & Praia de Camará, Marapanim & PA & Brazil & $\mathrm{oo}^{\circ} 35^{\prime} 18,79^{\prime \prime S}$ & $47^{\circ} 41^{\prime} 17,85^{\prime \prime} \mathrm{W}$ & 1 \\
\hline 9213 & Gymnuridae & Gymnura micrura & Praia de Camará, Marapanim & PA & Brazil & & & 1 \\
\hline 9214 & Potamotrygonidae & Styracura schmardae & Praia de Camará, Marapanim & PA & Brazil & oo $3446,81 ” S$ & $47^{\circ} 41^{\prime} \mathrm{o} 1,10^{\prime \prime} \mathrm{W}$ & 1 \\
\hline 9215 & Potamotrygonidae & Styracura schmardae & Praia de Camará, Marapanim & PA & Brazil & oo $3446,81 ” S$ & $47^{\circ} 41^{\prime} \mathrm{o} 1,10^{\prime \prime} \mathrm{W}$ & 1 \\
\hline 9216 & Potamotrygonidae & Styracura schmardae & Praia de Camará, Marapanim & PA & Brazil & oo $3446,81 ” S$ & $47^{\circ} 41^{\prime} \mathrm{o} 1,10^{\prime \prime} \mathrm{W}$ & 1 \\
\hline 9217 & Potamotrygonidae & Styracura schmardae & Praia de Camará, Marapanim & PA & Brazil & $\mathrm{oo}^{\circ} 344^{\prime} 6,81$ "S & $47^{\circ} 41^{\prime} \mathrm{o} 1,10^{\prime \prime} \mathrm{W}$ & 1 \\
\hline 9229 & Rhinobatidae & Pseudobatos percellens & Praia de Camará, Marapanim & PA & Brazil & & & 1 \\
\hline 9603 & Rhinobatidae & Pseudobatos percellens & Praia do Amor, Jacumã, Conde & $\mathrm{PB}$ & Brazil & & & 1 \\
\hline 9860 & Dasyatidae & Hypanus guttatus & Praia do Amor, Conde & PB & Brazil & & & 1 \\
\hline 10950 & Dasyatidae & Hypanus guttatus & Praia de Camará, Marapanim & PA & Brazil & $\mathrm{oo}^{\circ} 35^{\prime} 18,79^{\prime \prime S}$ & $47^{\circ} 41^{\prime} 17,85^{\prime \prime} \mathrm{W}$ & 1 \\
\hline 10951 & Dasyatidae & Hypanus guttatus & Praia de Camará, Marapanim & PA & Brazil & $\mathrm{oo}^{\circ} 35^{\prime} 18,79 ” \mathrm{~S}$ & $47^{\circ} 41^{\prime} 17,85^{\prime \prime} \mathrm{W}$ & 1 \\
\hline 10952 & Dasyatidae & Hypanus guttatus & Praia de Camará, Marapanim & PA & Brazil & $\mathrm{oo}^{\circ} 35^{\prime} 18,79 ” \mathrm{~S}$ & $47^{\circ} 41^{\prime} 17,85^{\prime \prime} \mathrm{W}$ & 1 \\
\hline 10953 & Dasyatidae & Hypanus guttatus & Praia de Camará, Marapanim & $\mathrm{PA}$ & Brazil & $\mathrm{oo}^{\circ} 35^{\prime} 18,79 ” \mathrm{~S}$ & $47^{\circ} 41^{\prime} 17,85^{\prime \prime} \mathrm{W}$ & 1 \\
\hline 10954 & Dasyatidae & Hypanus guttatus & Praia de Camará, Marapanim & PA & Brazil & $\mathrm{oo}^{\circ} 35^{\prime} 18,79 ” \mathrm{~S}$ & $47^{\circ} 41^{\prime} 17,85^{\prime \prime} \mathrm{W}$ & 1 \\
\hline 10955 & Dasyatidae & Hypanus guttatus & Praia de Camará, Marapanim & PA & Brazil & $\mathrm{oo}^{\circ} 35^{\prime} 18,79$ "S & $47^{\circ} 41^{\prime} 17,85^{\prime \prime} \mathrm{W}$ & 1 \\
\hline 10956 & Dasyatidae & Hypanus guttatus & Praia de Camará, Marapanim & PA & Brazil & $\mathrm{oo}^{\circ} 35^{\prime} 18,79^{\prime \prime S}$ & $47^{\circ} 41^{\prime} 17,85^{\prime \prime} \mathrm{W}$ & 1 \\
\hline 10957 & Dasyatidae & Hypanus guttatus & Praia de Camará, Marapanim & PA & Brazil & $\mathrm{oo}^{\circ} 35^{\prime} 18,79 ” \mathrm{~S}$ & $47^{\circ} 41^{\prime} 17,85^{\prime \prime} \mathrm{W}$ & 1 \\
\hline
\end{tabular}




\begin{tabular}{|c|c|c|c|c|c|c|c|c|}
\hline $\mathrm{CN}$ & Family & $\begin{array}{c}\text { Taxon } \\
\text { (full name) }\end{array}$ & Locality & $\mathbf{S}$ & Country & Latitude & Longitude & C \\
\hline 10958 & Dasyatidae & Hypanus guttatus & Praia de Camará, Marapanim & PA & Brazil & $\mathrm{oo}^{\circ} 35^{\prime} 18,79^{\prime \prime S}$ & $47^{\circ} 41^{\prime} 17,85^{\prime \prime} \mathrm{W}$ & 1 \\
\hline 10960 & Dasyatidae & Hypanus guttatus & Praia de Camará, Marapanim & PA & Brazil & $\mathrm{oo}^{\circ} 35^{\prime} 18,79$ ”'S & $47^{\circ} 41^{\prime} 17,85^{\prime \prime} \mathrm{W}$ & 1 \\
\hline 10961 & Dasyatidae & Hypanus guttatus & Praia de Camará, Marapanim & PA & Brazil & oo $^{\circ} 3447,76 ” \mathrm{~S}$ & $47^{\circ} 40^{\prime} 59,19 " \mathrm{~W}$ & 1 \\
\hline 10962 & Dasyatidae & Hypanus guttatus & Praia de Camará, Marapanim & PA & Brazil & oo $^{\circ} 3447,76 ” S$ & $47^{\circ} 40^{\prime} 59,19^{\prime \prime} \mathrm{W}$ & 1 \\
\hline 10963 & Dasyatidae & Hypanus guttatus & Praia de Camará, Marapanim & PA & Brazil & $0^{\circ} 34,47,76 ” S$ & $47^{\circ} 40^{\prime} 59,19 " \mathrm{~W}$ & 1 \\
\hline 10964 & Dasyatidae & Hypanus guttatus & Praia de Camará, Marapanim & PA & Brazil & $\mathrm{oo}^{\circ} 3447,76$ "S & $47^{\circ} 40^{\prime} 59,19$ ” W & 1 \\
\hline 10965 & Dasyatidae & Hypanus guttatus & Praia de Camará, Marapanim & PA & Brazil & oo $^{\circ} 3447,76 ” S$ & $47^{\circ} 40^{\prime} 59,19^{\prime \prime} \mathrm{W}$ & 1 \\
\hline 10966 & Dasyatidae & Hypanus guttatus & Praia de Camará, Marapanim & PA & Brazil & $0^{\circ} 34,47,76 ” S$ & $47^{\circ} 40^{\prime} 59,19^{\prime \prime} \mathrm{W}$ & 1 \\
\hline 10967 & Dasyatidae & Hypanus guttatus & Praia de Camará, Marapanim & PA & Brazil & $0^{\circ} 3447,76 ” \mathrm{~S}$ & $47^{\circ} 40^{\prime} 59,19 ” \mathrm{~W}$ & 1 \\
\hline 10968 & Dasyatidae & Hypanus guttatus & Praia de Camará, Marapanim & PA & Brazil & $\mathrm{oo}^{\circ} 344^{\prime} 6,81^{\prime \prime} \mathrm{S}$ & $47^{\circ} 41^{\prime} \mathrm{o}, 10 ” \mathrm{~W}$ & 1 \\
\hline 10969 & Dasyatidae & Hypanus guttatus & Praia de Camará, Marapanim & PA & Brazil & $\mathrm{oo}^{\circ} 344^{\prime} 6,81$ ” & $47^{\circ} 41^{\prime} \mathrm{O}, 10 ” \mathrm{~W}$ & 1 \\
\hline 10971 & Dasyatidae & Hypanus guttatus & Praia de Camará, Marapanim & PA & Brazil & $\mathrm{oo}^{\circ} 344^{\prime} 6,81$ ” S & $47^{\circ} 41^{\prime} \mathrm{O} 1,10 " \mathrm{~W}$ & 1 \\
\hline 10972 & Dasyatidae & Hypanus guttatus & Praia de Camará, Marapanim & PA & Brazil & $\mathrm{oo}^{\circ} 344^{\prime} 6,81$ ” & $47^{\circ} 41^{\prime} \mathrm{O} 1,10^{\prime \prime} \mathrm{W}$ & 1 \\
\hline 10973 & Dasyatidae & Hypanus guttatus & Praia de Camará, Marapanim & PA & Brazil & $\mathrm{oo}^{\circ} 344^{\prime} 6,81$ ” & $47^{\circ} 41^{\prime} \mathrm{O}, 10 " \mathrm{~W}$ & 1 \\
\hline 10974 & Dasyatidae & Hypanus guttatus & Praia de Camará, Marapanim & PA & Brazil & $\mathrm{oo}^{\circ} 34{ }^{\prime} 6,81$ 'S & $47^{\circ} 41^{\prime} \mathrm{O}, 10 " \mathrm{~W}$ & 1 \\
\hline 10975 & Dasyatidae & Hypanus guttatus & Praia de Camará, Marapanim & PA & Brazil & $0^{\circ} 3446,81$ 'S & $47^{\circ} 41^{\prime} \mathrm{o}, 10^{\prime \prime} \mathrm{W}$ & 1 \\
\hline 10976 & Dasyatidae & Hypanus guttatus & Praia de Camará, Marapanim & PA & Brazil & $\mathrm{oo}^{\circ} 344^{\prime} 6,81$ ” S & $47^{\circ} 41^{\prime} \mathrm{O} 1,10 " \mathrm{~W}$ & 1 \\
\hline 10977 & Somniosidae & Centroscymnus owstonii & $\begin{array}{l}\text { Oceano Atlântico, talude continental de } \\
\text { Pernambuco }\end{array}$ & $\mathrm{PE}$ & Brazil & & & 1 \\
\hline 11362 & Scyliorhinidae & Scyliorhinus haeckeli & Oceano Atlântico, costa do Rio Grande do Sul & RS & Brazil & $32^{\circ}{ }^{\circ} 10^{\prime} 43,8 ” S$ & $47^{\circ} 40^{\prime} 53,9 ” \mathrm{~W}$ & 1 \\
\hline 11363 & Carcharhinidae & Prionace glauca & Oceano Atlântico, costa do Rio Grande do Sul & RS & Brazil & $31^{\circ} 42438 ” S$ & $47^{\circ} 40^{\prime} 539^{\prime \prime} \mathrm{W}$ & 5 \\
\hline 11686 & Ginglymostomatidae & Ginglymostoma cirratum & Praia do Bessa, João Pessoa & $\mathrm{PB}$ & Brazil & & & 1 \\
\hline 11687 & Carcharhinidae & Rhizoprionodon porosus & Jacumã, Conde & $\mathrm{PB}$ & Brazil & & & 1 \\
\hline 11688 & Carcharhinidae & Rhizoprionodon porosus & Jacumã, Conde & $\mathrm{PB}$ & Brazil & & & 3 \\
\hline
\end{tabular}




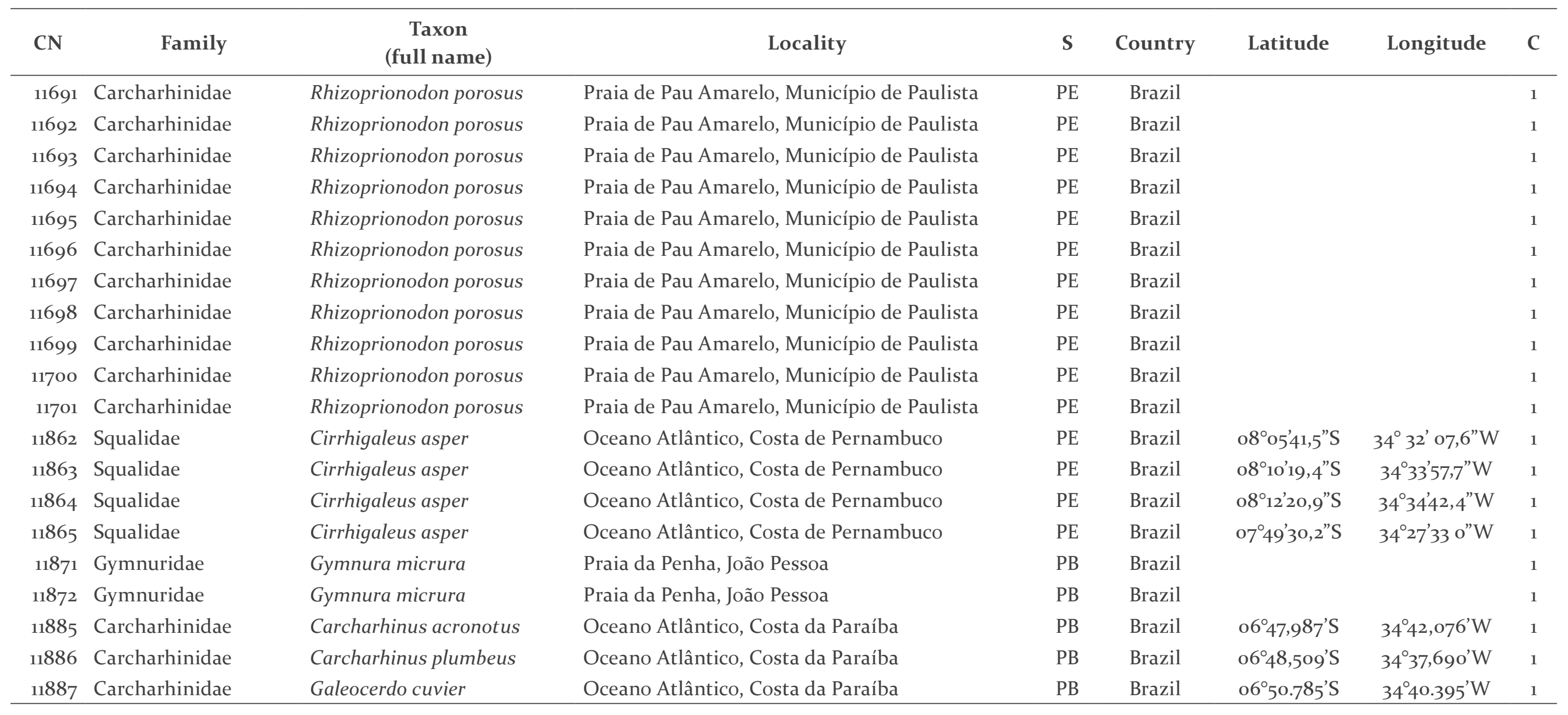

